Working Paper/Document de travail 2013-17

\title{
Fire-Sale FDI or Business as Usual?
}

\author{
by Ron Alquist, Rahul Mukherjee and Linda Tesar
}


Bank of Canada Working Paper 2013-17

June 2013

\title{
Fire-Sale FDI or Business as Usual?
}

\author{
by
}

\author{
Ron Alquist, ${ }^{1}$ Rahul Mukherjee ${ }^{2}$ and Linda Tesar $^{3}$ \\ 1International Economic Analysis Department \\ Bank of Canada \\ Ottawa, Ontario, Canada K1A 0G9 \\ ralquist@bankofcanada.ca \\ ${ }^{2}$ Department of Economics \\ Graduate Institute of International and Development Studies \\ 1202 Geneva, Switzerland \\ Corresponding author: rahul.mukherjee@graduateinstitute.ch \\ Web: https://sites.google.com/site/rahulmkiheid/ \\ ${ }^{3}$ Department of Economics \\ University of Michigan and NBER \\ Itesar@umich.edu
}

Bank of Canada working papers are theoretical or empirical works-in-progress on subjects in economics and finance. The views expressed in this paper are those of the authors. No responsibility for them should be attributed to the Bank of Canada. 


\section{Acknowledgements}

We thank Jean-Louis Arcand, Nicolas Berman, Satya P. Das, Iftekhar Hasan, Beata Javorcik, Andrei Levchenko, Ugo Panizza, Jing Zhang, and seminar participants at the University of Michigan Finance Day, the University of Vienna, the Bank of Portugal, HEC Lausanne, IHEID, the 2010 MEA Meetings, and the Indian Statistical Institute for comments. We are grateful to our discussant Uday Rajan for his thoughtful suggestions. Maggie Jim, Stela Rubinova, Argyn Toktamyssov, and Jingjing Xia provided excellent research assistance. Rahul Mukherjee gratefully acknowledges the support of the Centre for Finance and Development at IHEID. Linda Tesar gratefully acknowledges the support of the Ile-de-France DIMeco program. 


\begin{abstract}
Using a new data set, we examine the characteristics and dynamics of cross-border mergers and acquisitions during emerging-market financial crises, that is, so-called "firesale FDI.” Our findings shed fresh light on whether the transactions undertaken during crisis periods differ in fundamental ways from those undertaken during more tranquil periods. The increase in foreign acquisitions during crises is mainly driven by nonfinancial acquirers targeting firms in the same industry rather than foreign financial firms. This increase in acquisition activity in a given industry is unrelated to the industry's dependence on external finance. There is also no evidence of an increase in the size of stakes bought during crises. In terms of the effect of crises on emerging-market mergers and acquisitions, we find little evidence that foreign acquisitions are resold, or "flipped," more frequently than domestic acquisitions. Moreover, flipping rates are uncorrelated with the industry's dependence on external finance. Finally, the probability of being flipped to a domestic buyer does not differ across crisis and non-crisis periods. All of these results are robust to alternative empirical specifications, different definitions of crises, and the inclusion of macroeconomic controls. Contrary to conventional wisdom, fire-sale FDI and asset flipping by foreign firms appear to have been "business as usual."

JEL classification: F21, G01, G34

Bank classification: Financial markets; International financial markets; International topics
\end{abstract}

\title{
Résumé
}

S’appuyant sur un nouvel ensemble de données, les auteurs étudient les caractéristiques et la dynamique des fusions et acquisitions internationales pendant les crises financières qu'ont connues les marchés émergents. Les résultats leur permettent d’évaluer si les transactions effectuées en temps de crise diffèrent fondamentalement des opérations réalisées d'ordinaire. Durant les crises, les acquisitions étrangères augmentent, pour l'essentiel, plus du fait de repreneurs du secteur non financier intéressés par des entreprises évoluant dans leur branche d'activité que sous l'impulsion de sociétés financières étrangères. Cette hausse des acquisitions au sein d'une branche est sans rapport avec la dépendance des acteurs de cette branche à l'égard du financement extérieur. Rien n’indique non plus que les entreprises étrangères acquièrent de plus grandes parts de capital lors des crises. Quant à l'effet des crises sur les fusions et acquisitions dans les marchés émergents, il ne semble pas que les firmes aux mains de repreneurs étrangers soient revendues plus souvent que les firmes dont les acheteurs ne sont pas étrangers. Qui plus est, le rythme de revente n'est pas corrélé avec la dépendance des entreprises d'une branche à l'égard du financement extérieur. Enfin, la probabilité qu'une firme sous contrôle étranger redevienne la propriété de nationaux ne change pas en période de crise. Ces résultats ne sont pas sensibles à la spécification empirique retenue ni à la définition de la durée des crises et ne varient pas non plus quand des 
variables macroéconomiques de contrôle sont intégrées. Contrairement à ce qui est communément admis, les acquisitions financées par des investissements directs étrangers et le rythme de revente des entreprises ainsi achetées n'augmenteraient donc pas durant les crises financières.

Classification JEL : F21, G01, G34

Classification de la Banque : Marchés financiers; Marchés financiers internationaux; Questions internationales 


\section{Introduction}

"Fire-sale FDI" (foreign direct investment) was a term first coined by Krugman (2000) to describe the surge in foreign acquisitions of Asian firms during the 1997-98 financial crisis, even as portfolio investors sold off their holdings of Asian assets. Krugman cites anecdotal evidence from the business press that assets in countries affected by the crisis were sold to foreign investors at discounted prices due to the tightening of credit conditions, the sudden depreciation of the nominal exchange rate and the rapid deterioration in macroeconomic conditions. The general phenomenon of fire sales of both real and financial assets has been extensively studied in the finance literature (see Pulvino, 1998; Campbell et al., 2011; Shleifer and Vishny, 1992, 1997). In addition, several important policy questions such as the transfer of corporate control to foreign residents, the possibility of overinvestment by foreign firms and the relative desirability of foreign direct investment compared with other types of international capital flows (e.g., Loungani and Razin, 2001; Mody and Negishi, 2001) hinge crucially on the existence of fire-sale foreign direct investment during emerging-market crises.

Establishing definitive evidence of fire sales in emerging markets, however, has proven challenging. One issue is that a test for a fire sale of assets requires knowing how asset prices and cross-border transactions would have evolved in the absence of the crisis. It is difficult to predict equilibrium asset prices even under normal conditions, let alone during periods of financial stress. In addition, during the past 20 years the surge in foreign investment in emerging markets coincided with a wave of cross-border acquisitions and a surge in domestic mergers in emerging markets. While the expansion of transactions in Asia seems impressive relative to the pre-crisis level of acquisitions in emerging markets, it is less dramatic when viewed against the larger backdrop of global merger and acquisition activity. Finally, the crisis coincided with, and in some cases was the precipitating factor for, the deregulation of the market for corporate control in many emerging markets. By focusing on data leading up to and during the crisis, it is all but impossible to disentangle the effect of the crisis from the effect of reducing barriers to foreign ownership.

To overcome these challenges, this paper studies a large panel of corporate transactions in emerging markets over a long period of time. The database contains approximately 32,000 foreign and domestic acquisitions spanning the period between 1990 and 2007 in sixteen emerging markets. The variety of transactions in the database permits us to compare crisis-time cross-border transactions with domestic transactions in emerging markets and with a large sample of non-crisis transactions. The identification of crisis effects is facilitated by the fact that crises occur at different times and in some countries but not in others. Furthermore, because the sample includes the period after the Latin American and Asian financial crises in the mid- and late-1990s, we can conduct direct comparisons between corporate transactions that occurred during the crisis period

with those that occurred during less volatile periods and during periods when there were fewer such transactions. 
We examine six distinct implications of fire sales during crisis episodes in this paper. The first three results are related to the identity and composition of acquirer-target matches during financial crises. First, we ask whether the national and sectoral identities of acquirer-target matches differ during crises. Our results indicate that the frequency of foreign acquisitions increases during banking and currency crises, confirming the findings of Aguiar and Gopinath (2005) among others. This tendency is more pronounced for foreign non-financial acquirers targeting firms in the same Standard Industrial Classification (SIC) code. It runs counter to the view that the increase in foreign acquisitions is primarily driven by foreign financial firms acquiring either other financial firms or non-financial firms. Second, to shed light on the composition of crisis-time FDI, we examine whether sectors that are more dependent on external finance experience a greater incidence of foreign acquisitions during banking and currency crises. The evidence indicates that even though external-finance-dependent sectors are more likely to be the target of FDI, this characteristic is uncorrelated with the incidence of a banking and currency crisis in the target country. Third, we test whether foreign firms acquire larger stakes in the target firm during crises, which could be the case if the cost of acquiring shares is relatively low during crises or if asymmetric information and agency problems can be circumvented by gaining control. Contrary to the results reported in Acharya et al. (2011), there is no evidence of an increase in the frequency of a controlling stake being acquired or in the size of the controlling stake acquired during crises.

The second set of results is related to the duration of crisis-time matches and is the key contribution of the paper. To the best of our knowledge, this paper is the first to examine the post-acquisition dynamics of firm ownership in emerging markets using a large panel of countries spanning a long period of time. We first conduct a duration analysis on the length of acquirer-target relationships initiated during and outside of crisis periods. Acquisitions made during a fire sale may be driven by short-run, speculative motives rather than according to long-term investment plans (Acharya et al., 2011). If that were the case, the cohort of crisis-time acquisitions would experience increased rates of divestiture when asset markets recovered following the crises. The observable implications of this behavior are a shorter duration of the acquirer-target relationship and a higher frequency of divestiture for acquisitions made during crisis episodes. We provide a number of results regarding the "turnover rate" of such acquisitions, which is defined as the probability of a firm being a target after being acquired once. The fourth main result of the paper is that there is little evidence that crisis-time foreign acquisitions have a higher turnover rate. In other words, foreign acquisitions during crises are not flipped at faster rates than crisis-time domestic acquisitions.

We also examine whether the duration of crisis-time acquisitions is influenced by dependence on external finance. Some sectors of the economy may be more prone to acquisitions driven by opportunistic or speculative motives during crises. The fifth result is that the degree of external finance dependence bears no significant relationship with the turnover rate of acquisitions in those industries, either in or out of crises. Next, in the cases where targets are flipped, the data provide 
some insight into the types of firms that flip assets in emerging markets and the types of firms that are subsequent buyers of the flipped target. About a third of "flippers" are foreign, which is about the same proportion of foreign firms in the overall sample. In cases where foreign acquisitions are flipped, the probability of being flipped to a domestic buyer is no greater if the foreign acquisition was originally undertaken during a banking crisis. Thus, the sixth result is that the regression evidence is inconsistent with the flipping of crisis-time asset purchases to domestic firms by foreign acquirers.

Although several papers have examined acquisitions and subsequent divestitures in the United States (Ravenscraft and Scherer, 1991; Kaplan and Weisbach, 1992; Bergh, 1997), few have focused on the prevalence of this phenomenon in emerging markets. One exception is Holan and Toulan (2006), who look at divestitures by foreign companies in Argentina between 1990 and 2002. More recently, Rossi and Volpin (2004) and Erel et al. (2012) study the cross-country determinants of acquisitions for a cross-section of different countries. In contrast to the last two papers, the primary focus of this study is the divestiture process in emerging markets. Although we control for macroeconomic variables in our regressions and can make statements about the aggregate determinants of acquisitions and divestitures, we focus on the differences between crisis-time and normal-time acquisition and divestiture patterns.

Our paper is related to the literature on country-level fire sales, as exemplified by Aguiar and Gopinath (2005). They explicitly test for a relationship between firm-level liquidity and foreign acquisitions in Asia. They find that the number of foreign acquisitions increased by $91 \%$ in the period leading up to and after the liquidity crisis in Asia in 1996-98, whereas domestic transactions declined by $27 \%$. This conclusion mirrors our findings of an increase in the probability of foreign acquisitions. They also find that during the Asian crisis the probability of a firm being acquired is a decreasing function of the firm's liquidity position, while the offer price to book value ratio turns out to be an increasing function of firm liquidity. These two liquidity effects were prominent only in 1998, suggesting that a shortage of aggregate liquidity was a key determinant of these sales. The findings of Aguiar and Gopinath (2005) motivate us to examine the effect of external finance dependence as a factor driving crisis-time acquisitions.

An alternative approach to studying fire sales is to analyze returns to acquisitions during crises. An implication of the fire-sale hypothesis is that there should be large abnormal returns for the acquiring firm during periods when the target firm experiences distress. Using an event study methodology, Chari et al. (2010) find that developed-market firms experienced significant positive abnormal returns at the time of a controlling acquisition of an emerging-market firm. However, abnormal returns are also present in long periods of data and do not depend on crisis conditions in the target country. Furthermore, these returns can be explained by the acquisition of control over intangible assets in economic environments where corporate governance is weak. The acquisition of foreign assets can thus be interpreted as a mechanism for completing the market in these economic 
environments rather than as an opportunity to take advantage of depressed asset prices during a financial crisis. The evidence presented in this paper is consistent with the evidence obtained from asset prices in Chari et al. (2010). Just as Chari et al. (2010) find little evidence of fire sales in asset prices, this paper finds only weak evidence of fire sales based on cross-border acquisitions and divestitures.

The paper is also related to Acharya et al. (2011). They construct and test a theoretical model in which distressed firms are purchased by foreign acquirers that, in turn, resell (or flip) the target after the crisis ends and asset markets recover. In a sample of approximately 7,000 transactions, they find some evidence of flipping and an increase in controlling stakes during crises. The size and scope of the database that we constructed enables us to examine these hypotheses with a richer set of country and crisis controls. As we discuss below, there is no strong evidence of flipping in these data.

The rest of the paper is organized as follows. We describe the data set in section 2. We then report our results on the composition of cross-border mergers and acquisitions, duration during crises and the identity of buyers of flipped deals in sections 3, 4, and 5. Section 6 concludes.

\section{Data}

We use data from SDC Thompson's International Mergers and Acquisitions database, which reports public and private merger and acquisition (M\&A) transactions involving at least a $5 \%$ ownership stake in the target company. SDC collects information from more than 200 English and foreign language news sources, U.S. Securities and Exchange Commission filings, as well as the filings from SDC's international counterparts, trade publications, newswire reports, and proprietary surveys of investment banks, law firms, and other advisory firms. For each transaction, the SDC database provides target- and acquiring-firm characteristics, including the names of the firms; their country of origin, industry, and primary SIC classification; the per cent of shares sought and finally acquired in the transaction; and the date by which the transaction was completed.

The data set contains all domestic and foreign acquisitions that took place between 1990 and 2007 and for which the target is located in one of sixteen emerging markets: Argentina, Brazil, Chile, China, India, Indonesia, Malaysia, Mexico, Peru, Philippines, Singapore, South Africa, South Korea, Taiwan, Thailand and Vietnam. Although the database includes mergers as well as acquisitions, mergers account for only a small fraction of total cross-border transactions. For this reason, we refer to acquisitions in describing the data below. Wherever sample sizes allow us to do so, we check whether there are differences in results across different subsamples; in particular, Asia, post-1997 Asia and the sample of non-Asian countries. Our motivation for this lies in potential regime differences across Asia and Latin America, as well as pre- and post-crisis Asia.

The identification of the crisis effects relies on a comparison of transactions undertaken during crisis and non-crisis periods. The time series and cross-sectional variation in the occurrence of 
crises is therefore key to the identification of these effects, so it is important that the definition of the beginning and the end of each crisis is as accurate as possible. In the benchmark results, we use the annual crisis dates identified in Laeven and Valencia (2010) for systemic banking crises and in Laeven and Valencia (2008) for currency crises. ${ }^{1}$ Most of the results reported in the body of the paper use the Laeven and Valencia (2010) banking crisis dates as the definition of a crisis. About $12 \%$ of the transactions in our sample take placing during banking crises, while only about $3.3 \%$ and $2.5 \%$ take place during currency and twin crises, respectively. Thus tests of significance of crisis effects that rely only on currency or twin crises lack power. This fact motivates our use of banking crises as our benchmark definition of a financial crisis, but we also perform robustness checks by including both banking and currency crisis episodes in our definition. To assess the sensitivity of the results to alternative definitions of the crises, we use the data on systemic banking crises and currency crises from Reinhart and Rogoff (2009).

We include a number of additional controls in the regressions. To check whether the extent of foreign ownership matters for our results, we include two alternative variables - the fraction of a firm acquired during a transaction and the fraction of a firm owned after a transaction. ${ }^{2}$ In addition, country- and industry-level controls are used as covariates. Four of these variables are related to macroeconomic conditions in the country. They are the change in the nominal exchange rate (quarterly), the use of IMF credit and loans as a percentage of a country's quota (quarterly), real GDP per capita, and real GDP growth (the last two at annual frequency because of data availability). ${ }^{3}$ The data are from the IMF International Financial Statistics, the National Statistical Office (for Taiwan) and the Central Bank of the Republic of China (for China). These macroeconomic controls have been used to account for country-level, aggregate conditions that

\footnotetext{
${ }^{1}$ Laeven and Valencia (2010) define a banking crisis as systemic if two conditions are met: (1) there are significant signs of financial distress in the banking system (as indicated by significant bank runs, losses in the banking system and bank liquidations); and (2) there are significant banking policy intervention measures in response to significant losses in the banking system. Policy measures are defined to be significant if at least three of the following conditions are met: (1) extensive liquidity support is provided ( $5 \%$ of deposits and liabilities to non-residents); (2) bank restructuring costs exceed $3 \%$ of GDP; (3) systemically important banks are nationalized; (4) guarantees of bank liabilities are put into place; (5) asset purchases from financial institutions exceed 5\% of GDP; and (6) deposit freezes and bank holidays are introduced. In their definition of currency crises, Laeven and Valencia (2008) build on the approach of Frankel and Rose (1996). They define a currency crisis as a nominal depreciation of the currency of at least $30 \%$ that is also at a least a $10 \%$ increase in the rate of depreciation compared to the year before. They use the per cent change of the end-of-period nominal bilateral exchange rate from the World Economic Outlook database of the IMF to identify currency crises. For countries that meet the criteria for several continuous years, they use the first year of each 5 -year window to identify the crisis. The set of episodes identified by this procedure also includes large devaluations by countries that adopt fixed exchange rate regimes.

${ }^{2}$ These two can be different when an acquiring firm already has an existing stake in a target.

${ }^{3}$ We exclude a commonly used control variable, the real interest rate, because of data availability. We have complete coverage of years and countries at the yearly frequency for real GDP per capita and real GDP growth, and at the quarterly frequency for the nominal exchange rate and the use of IMF credit and loans as a percentage of a country's quota. The coverage for both quarterly and yearly real interest rates is sparse for a few countries in the early years of our sample. In particular, the quarterly data for real interest rates has missing values for the following countries and years: Argentina (until 1993Q1), Brazil (until 1997Q4), Mexico (until 1993Q3), and Vietnam (until 1995Q4).
} 
may influence the decision to acquire a firm (e.g., Brown and Dinc, 2011), over and above the extraordinary circumstances of financial stress that characterize banking or currency crises. When conducting our analysis of the manufacturing industry, we use the index of sectoral dependence on external finance from Rajan and Zingales (1998).

\subsection{Features of the Mergers and Acquisitions Data}

Figure 1 depicts the value of acquisitions by foreign firms and FDI in Latin America and Asia. It shows the surge in acquisitions in Latin America in 1996-1998 following the Mexican crisis in 1995 and the subsequent surge in capital flows into Asia in 1999. Acquisitions in both regions leveled off in the early 2000s and increased again in Asia after 2004. Figure 2 decomposes the acquisitions in each region into foreign and domestic transactions. This figure reveals that the increases in foreign acquisitions in each region coincided with increases in domestic transactions.

Table 1 shows the total number of transactions by year and by country of the target. Our database includes 31,999 transactions, of which 11,462 involve a foreign acquirer. ${ }^{4}$ The largest number of acquisitions occur in Brazil, China, India, Malaysia, Singapore and South Korea. Approximately two-thirds of all transactions occur in Asia and the remaining third occur in Latin America. About $60 \%$ of all transactions in Latin America involve a foreign acquirer, while only about a third of all transactions involve a foreign acquirer in Asia. The share of foreign acquirers varies across countries, but it is generally stable over time.

The breakdown of foreign acquirers by the country of the acquirer is shown in Table 2 . The United States accounts for a little over a quarter of foreign acquisitions in emerging markets, Europe another quarter and Asia about a third. When the transactions are broken down by one-digit SIC code (see Table 3), the data indicate that about one-third of acquiring firms in emerging markets are in the finance, insurance and real estate (FIRE) sector and another third are manufacturing firms. The breakdown by industry is similar for targets (Table 4) and for both domestic and foreign transactions. Table 5 shows the industry decomposition by both acquiring firm and target firm. While many transactions occur between firms in different sectors, the majority of transactions occur within the same one-digit SIC code (e.g., foreign firms in the FIRE sector acquire firms in emerging markets that are also in the FIRE sector).

Table 6 decomposes the transactions by the share of the firm that the target owned after the acquisition was completed. In approximately $70 \%$ of the transactions, the acquirer obtains an ownership stake of $50 \%$ or more of the target. In $45 \%$ of all domestic transactions and $48 \%$ of the foreign transactions, the acquirer becomes the sole owner of the target. Thus, in almost half of all cases the acquiring firm obtains a controlling stake in the foreign target.

\footnotetext{
${ }^{4}$ For our regression results later, we use two definitions of a foreign firm. A "foreign" acquirer is defined as either (1) a firm from a developed country, or (2) a non-domestic acquirer. Our reported results are based on the first definition. The results are not sensitive to this choice because most of the foreign acquirers are from countries in North America, Europe or Asia that are classified as developed markets.
} 


\section{Characteristics of Crisis Transactions}

\subsection{Does the Composition of Transactions Change During Crises?}

A key question is whether the composition of transactions - in terms of the sectors to which acquirers and targets belong, and the national identity of acquiring firms - changes during crisis periods. Aguiar and Gopinath (2005) and Acharya et al. (2011) find evidence suggesting that, during crises, domestic firms become credit constrained. Foreign firms unaffected by the crisis have access to greater liquidity and can therefore take advantage of buying opportunities in the countries affected by the crisis. These buying opportunities may be exploited by foreign firms in related industries because they have greater resources to complete acquisitions compared to domestic firms, or by foreign financial firms that see an opportunity to buy firms and then resell them to domestic firms after the crisis abates. Foreign non-financial firms outside of the target's industry may complete acquisitions more often during crises to take advantage of fire-sale prices for motives similar to those of financial firms, or for strategic reasons such as diversification.

To test this hypothesis, we use a linear probability model to estimate the increase in likelihood during crises of particular categories of acquisitions (e.g., foreign acquisitions). ${ }^{5}$ We estimate the model:

$$
P\left(D_{l}^{k j c t}=1 \mid \cdot\right)=\alpha+\beta_{C} D_{c t}+\beta_{f} f r a c_{k}+\beta_{j c} \boldsymbol{\delta}_{j c}+\beta_{m c} \text { controls } s_{c t}+\epsilon_{k j c t},
$$

where $k, j, c$ and $t$ stand for transaction, single-digit SIC industry of the target firm, country and time, respectively. The dependent variable in each estimation is a dummy $\left(D_{l}^{k j c t}\right)$ that takes a value of 1 if a transaction belongs to category $l$ and 0 otherwise. For example, when comparing the likelihood of a transaction being completed by a foreign acquiring firm during a crisis to the same likelihood in a non-crisis period, the regressand is a "Foreign Acquisition Dummy," $D_{F}^{k j c t}$, that is 1 when the acquiring firm involved in transaction $k$, in industry $j$, in country $c$, at date $t$, belongs to the category "foreign firm," and 0 otherwise.

The vector of explanatory variables includes: a crisis dummy $D_{c t}$ that varies across countries and time, a vector of country $\times$ target-industry dummies $\boldsymbol{\delta}_{\boldsymbol{j}}$, and the percentage $\mathrm{frac}_{k}$ of the target firm that is acquired in transaction $k$. In addition, a vector of country-level macroeconomic

\footnotetext{
${ }^{5}$ The choice of the linear probability model as our baseline over non-linear models such as logit or probit is based on several considerations. First, identification of the crisis effect requires country $\times$ target-industry fixed effects. If foreign acquiring firms are always more active in certain countries, and a crisis occurs in these countries, then the estimated coefficient on the country-level crisis dummy will ascribe part of the country effect to the crisis. Probit suffers from the incidental parameters problem when using maximum likelihood estimation, so the parameters of the model with fixed effects cannot be consistently estimated with dummy variables. While logit does not have this issue, a large number of right-hand-side variables sometimes causes problems with computational convergence, and we lose some information because any country $\times$ target-industry that has no variation in the left-hand-side variable is automatically dropped. We thus use the linear probability model for the ease with which it can handle the panel nature of our data and for its interpretability, and also because $99.9 \%$ of our predicted probabilities lie between 0 and 1 (see Horrace and Oaxaca (2006)). Results from a logit model yield qualitatively similar conclusions.
} 
controls controls $s_{c t}$ - per capita GDP, GDP growth, currency depreciation and use of IMF credit as a percentage of quota - are included in the regressions as proxies for aggregate conditions in the country of the target firm. ${ }^{6}$ The fraction acquired in a transaction is included to control for acquisitions of different size. The coefficient of interest is $\beta_{C}$. In the results that follow, a "foreign" acquirer is defined as a firm located in a developed market unless noted otherwise, and a "financial" firm is one in the FIRE sector.

Standard errors are clustered two-way at the level of country $\times$ target-industry and month, except for the regressions that restrict attention to the financial targets. The standard errors from those regressions are clustered two-way at the country and month level. ${ }^{7}$ The rationale for clustering in this way is that there may be serial correlation between errors within the same country-industry combination attributable to a time-varying factor not fully captured by fixed effects at that level, as well as correlation among different firms across all countries and industries within the month due to common shocks. ${ }^{8}$

The estimated coefficients of the linear probability model are reported in Table 7, which shows the composition of foreign acquisitions in and out of banking crises in the countries where targets are located. For this and later tables, "row" refers to the line containing the estimated coefficients. For example, row 1 and row 2 report the coefficient on the banking crisis dummy (the coefficients on the control variables are not reported, for brevity) when the dependent variables are a dummy variable indicating whether an acquisition was carried out by a foreign firm and a foreign financial firm, respectively. The model is also estimated using the Reinhart and Rogoff (2009) crisis dates and with a dummy indicating whether a transaction took place during either a banking or a currency crisis. The results are similar to the ones reported here because most of the currency crises in the sample were also associated with banking crises.

Several interesting results emerge. Row 1 of Table 7 tells us that across all four samples, the likelihood of being acquired by a foreign firm is significantly higher during a banking crisis than during normal times, echoing the findings of Aguiar and Gopinath (2005) and Acharya et al. (2011). A comparison of rows 3 and 2 tells us, however, that this change is more pronounced for a foreign acquiring firm from the non-financial sector than from the financial sector. There is some variation across subsamples, with acquisitions by foreign financial sector firms being less prominent in Asia than in Latin America and South Africa, while exactly the opposite is true for foreign non-financial sector firms. It is also worth noting from row 4 that acquisitions by foreign non-financial acquirers

\footnotetext{
${ }^{6}$ Because they vary across country and time, they are not redundant when coupled with our country-industry fixed effects.

${ }^{7}$ See Petersen (2009).

${ }^{8}$ Errors for a particular firm are likely to be correlated across time, but target firms are always nested in the same country-industry group. Thus, following Bertrand et al. (2004), Cameron et al. (forthcoming) and Cameron and Miller (2010), we cluster at the highest level of aggregation, which in our case is a country-industry group. We prefer clustering at this level rather than a higher one, such as country or industry, because the crisis-related shocks might be specific to certain industries within crisis-hit countries and a particular industry exists in all countries.
} 
of non-financial targets are also more likely during banking crises. ${ }^{9}$

The same pattern of primacy of the non-financial sector emerges when one examines the sectoral identity of the foreign acquirers' targets in rows 5 and 6 of Table 7 . The likelihood of experiencing a foreign acquisition goes up by more for a non-financial sector target than for a financial sector target. In fact, the probability of a foreign firm acquiring a financial target during banking crises does not change at all compared with non-crisis times. This finding underscores the point that the surge of FDI in the financial sector of countries hit by banking crises may have been simply a result of contemporaneous deregulation rather than an intrinsic characteristic of banking crises, something that is missed by studies that fail to compare the crisis period to both the pre- and post-crisis periods together. Acquisitions of targets in the same industry by foreign non-financial firms increase during banking crises (row 7), which shows that within-industry foreign acquisitions are not driven exclusively by foreign financial firms acquiring financial firms. ${ }^{10}$ In summary, the increase in foreign acquisitions during financial crises appears to be driven mainly by non-financial acquirers targeting firms in the same industry, rather than by foreign financial firms.

\subsection{Does External Finance Dependence Matter for Crisis Acquisition Patterns?}

The previous section shows that, when comparing periods of financial crises to non-crisis periods in emerging markets, non-financial firms rather than financial firms seem to increase their acquisition activity to a greater degree. Although this result calls into question the traditional account of foreign financial firms leading a surge of FDI in the distressed sectors of the economy, it remains possible that financial factors played a role in driving those acquisitions. Acquisitions may be driven by financial stress if the targets being acquired during crises are those that rely on external finance. If such finance is harder to come by during crises, then we could still have fire-sale FDI, as in Aguiar and Gopinath (2005).

We test whether external finance dependence of an industry predicts acquisition patterns during banking crises using the same linear probability model as before. ${ }^{11}$ The external finance dependence measure is available only for the manufacturing sectors (one-digit SIC 2 and 3), so we restrict attention to those for the industry analysis. This leaves us with 11,012 transactions comprising about $32 \%$ and $39 \%$ of the domestic and foreign acquisitions in the full sample.

The following model is estimated:

\footnotetext{
${ }^{9}$ Hence the result in row 3 that non-financial sector acquirers are acquiring more often is not driven by them acquiring financial sector firms in distress during the banking crisis.

${ }^{10}$ An examination of the change in the likelihood of a foreign financial firm acquiring a financial firm across banking crises and normal times shows that this change is not as pronounced as the result for the non-financial sector, which is reported in Table 7 . These results are available upon request.

${ }^{11}$ The results using the currency crisis dummies and the sensitivity analysis using the logit model are available upon request.
} 


$$
\begin{array}{r}
P\left(D_{l}^{k j c t}=1 \mid \cdot\right)=\alpha+\beta_{C} D_{c t}+\beta_{\text {ext }} \text { extfin } \\
j \\
\beta_{f} \text { frac }_{k}+\beta_{C, \text { ext }} D_{c t} \times \boldsymbol{\delta}_{c}+\beta_{m c} \text { controls } \text { ext }_{c t}+\epsilon_{k j c t}
\end{array}
$$

The vector of explanatory variables now includes the crisis dummy $D_{c t}$, the sectoral index of

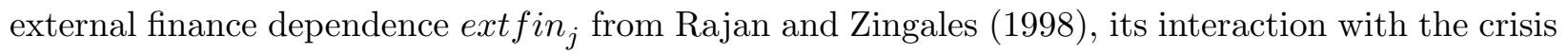
dummy, a vector of country dummies $\boldsymbol{\delta}_{\boldsymbol{c}}$ (as opposed to country $\times$ target-industry dummies) and the control variables discussed in the previous section. ${ }^{12}$ The standard errors are clustered two-way at the level of country $\times$ target-industry and month.

Table 8 reports the results. Looking first at the full sample of countries (Panel A, row 1), more external-finance-dependent manufacturing sectors are more likely to experience acquisitions in which the acquiring firm is foreign, irrespective of the sector of the acquiring firm. However, this likelihood is much larger for foreign non-financial sector firms (column 3) than for financial sector firms (column 2). Foreign financial and manufacturing sector acquirers acquire targets no more frequently in sectors that are dependent on external finance in Asia (Panel B, row 1, columns 2 and 4). What is more interesting is that the interaction of the external-finance-dependence measure and the banking crisis dummy is never significant. In one of the first empirical investigations of asset fire sales in the literature, Pulvino (1998) finds that fire sales of used aircraft are associated with asset purchase by industry outsiders, especially during market downturns. Motivated by this finding, the last column of Table 8 asks whether acquisitions by non-manufacturing industry firms are correlated with external finance dependence of the target firm's industry during financial crises. We fail to find such an effect.

Altogether, this evidence indicates that external finance dependence is neither more nor less critical during banking crises - a surprising finding given the presumed importance of fire-sale FDI in crisis-time Asia. Similar conclusions obtain for banking and currency crises, but they are not reported here, for brevity. Using alternative crisis dates from Reinhart and Rogoff (2009) yields qualitatively similar results. External finance dependence is not a factor driving these acquisitions.

\subsection{Does the Degree of Corporate Control Sought Change During Crises?}

Another question that has received attention and that is important in assessing the differences between FDI during crisis and normal periods is whether larger controlling stakes are acquired during crises. With the asset prices of domestic target firms depressed during a crisis, foreign acquirers may find it more profitable to acquire controlling stakes and acquire a larger share of a particular target firm conditional on acquiring control. As before, we use a simple OLS framework as the baseline specification to address both of these questions and perform robustness checks

\footnotetext{
${ }^{12}$ Industry-level fixed effects are excluded from this specification because the industry characteristics we use are time invariant.
} 
(available upon request) with the generalized linear models (GLM) based methods suggested by Papke and Wooldridge (1996). For the first question, we define a binary dummy $D_{\text {control }}^{k j c t}$ that takes a value of 1 if a controlling stake (i.e., $50 \%$ or more) in the target is acquired at time $t$, in the transaction $k$, in country $c$ and industry $j$, and 0 otherwise. ${ }^{13}$ The estimated model is

$$
P\left(D_{\text {control }}^{k j c t}=1 \mid \cdot\right)=\alpha+\beta_{C} D_{c t}+\beta_{j c} \boldsymbol{\delta}_{j c}+\beta_{m c} \text { controls } \boldsymbol{c t}_{\text {ct }}+\epsilon_{k j c t} .
$$

The regressors in this specification are a vector of country $\times$ target-industry dummies $\boldsymbol{\delta}_{\boldsymbol{j} \boldsymbol{c}}$, the four country-level macroeconomic controls control $s_{c t}$ used before, and the variable of interest - a dummy $D_{c t}$ indicating whether the transaction took place during a domestic financial crisis.

The results for banking crises are reported in Table 9, while those for currency crises are available upon request. As in Tables 7 and 8, each row of results is for a given category of transactions. For example, the first row asks whether control was acquired more often by foreign acquiring firms when targeting any firm in our sample of countries. None of the coefficients in the table are significant, indicating that the patterns of acquiring control do not differ between crisis and non-crisis periods in any of our samples. ${ }^{14}$ This evidence again shows the importance of comparing the crisis with both the pre- and post-crisis periods, since the comparison between the crisis and the pre-crisis period, which typically has more restrictions on foreign ownership, may bias the results toward finding more control being acquired during crisis periods.

Next, we estimate an OLS regression on the subsample of firms for which at least a $50 \%$ stake was acquired, where the dependent variable $D_{\text {control }}^{k j c t}$ is replaced by $f r a c_{k j c t}$, the actual fraction of a firm acquired in transaction $k$ in industry $j$, country $c$ and time $t$. The set of explanatory variables is unchanged:

$$
\operatorname{frac}_{k j c t}=\alpha+\beta_{C} D_{c t}+\beta_{j c} \boldsymbol{\delta}_{j c}+\beta_{m c} \text { controls } \boldsymbol{s}_{c t}+\epsilon_{k j c t} .
$$

Table 10 reports these results. For the subset of firms for which a controlling stake of at least $50 \%$ was acquired, crisis-time acquisitions typically involved the same or a lower share of the firm being bought. Because fire sales are typically associated with the acquisition of larger stakes due to depressed asset prices, this finding can be seen as indirect evidence that such sales are not a robust feature of emerging-market crises in general, and the Asian financial crisis in particular. GLM estimates (see Papke and Wooldridge (1996)), which take into account that frac $_{k j c t}$ is bounded between 0 and 1 , confirm these results and are available upon request.

\footnotetext{
${ }^{13}$ We use four different definitions of a controlling stake using two cut-offs ( $50 \%$ and $100 \%$ ) and two different measures: the fraction acquired in a transaction and the fraction owned after a transaction. To save space, we report results only for controlling stakes defined as a fraction acquired of at least 50\%. Our main results are not sensitive to the definition of a controlling stake.

${ }^{14}$ The results from logit regressions, varying the definition of control to include only $100 \%$ acquisitions, including both banking and currency crises, and using the Reinhart and Rogoff (2009) dates, are available upon request. The main conclusions are insensitive to these changes.
} 


\subsection{Summary of Results}

There are three main conclusions that we can draw from this section. First, the marked increase in foreign non-financial firms acquiring non-financial targets is the primary feature of emergingmarket financial crises. Second, the external finance dependence of a sector seems to have played no role in determining the likelihood of acquisitions during crises. Third, the patterns of acquiring control do not change during crises. In general, these conclusions are robust to alternative econometric specifications and the use of different crisis dates.

\section{The Duration of Crisis-Time Acquisitions}

In this section, we examine the duration of the relationship between an acquirer and its target and whether the duration of the relationship differs for acquisitions that occurred during crises. To the best of our knowledge, this paper is the first to analyze the ownership dynamics of emergingmarket acquisitions in general and crisis-time acquisitions in particular. Duration is measured by identifying firms that appear two or more times in the database - first as a target in an initial transaction, which identifies the beginning of the relationship. If the firm appears a second time as a target, we postulate that the firm is being divested from the first transaction (when the target firm appears in the data only twice) or from the immediately preceding transaction (when the target firm appears more than twice). The second (or subsequent) sale thus marks the end of the relationship. The duration is defined as the length of time between each transaction involving the same target.

If a target does not appear in the database after the initial transaction, it could mean one of three things. First, the firm may have never become a target again (in which case we correctly code the initial relationship as continuing); second, the firm may have gone out of business (and we miscode the relationship as continuing); or third, the firm may have been reorganized by the first buyer under a different name and thus does not show up as a target under the same name (and, again, we miscode the initial relationship as continuing). To correct for the errors related to the renaming of the target firms, we manually checked whether the firms that did not appear more than once in the data set were renamed and corrected that error where possible. We cannot correct for the errors related to a firm going out of business, because there is no way of determining this from our data set.

Another source of error is that in partial acquisitions, pieces of the target may be owned by different entities. Because SDC reports the identity of the firm or parties on the selling side only in a small percentage of the total transactions, it is impossible in the vast majority of the cases to confirm at the time of the second transaction that the initial buyer of the target is now the seller. We can only verify that the target appears again (as a target) in the sample. To address this type of error, we re-estimate our models on the subset of targets that were fully acquired in the initial 
transaction. By including only full acquisitions, we are certain that the subsequent seller was the original buyer. Although this procedure reduces the number of transactions in the sample, we still capture most of the controlling transactions (at or above the $50 \%$ stake threshold) in our sample. As Table 6 shows, the number of transactions falls from 22,733 to 15,064. Thus, full acquisitions account for almost two-thirds of the transactions in which a majority stake was acquired.

The object we estimate is the hazard function, which captures the risk of a member of the population being acquired again a certain number of days after its last acquisition. The hazard function $h\left(t_{i}\right)$ defines the probability that firm $i$ will experience an acquisition event in the interval of time $\Delta t_{i}$, conditional on the fact that it has not been the target of an acquisition for $t_{i}$ units of time since the last acquisition. ${ }^{15}$ Under the assumption that most acquisitions on the buyer side involve a divestiture on the seller side, the hazard is also a reliable measure of the typical frequency of divestiture for the average firm or the turnover of M\&A transactions. ${ }^{16}$

The duration data from the sixteen countries are pooled together and analyzed using the Cox proportional hazards model (see Cleves et al. (2008)). The key assumption is that hazard rates are proportional to the baseline hazard across different patterns of explanatory variables. While the model assumes no parametric form for the baseline hazards, it posits a functional relationship between hazards for different explanatory variables. Let $h_{j c}(t)$ be the hazard function as defined before, where $j$ and $c$ denote industry and country, respectively. Then the Cox model we estimate can be written as

$$
h_{j c}(t \mid x)=h_{j c}(t) \mathrm{e}^{x^{\prime} \beta} \quad \text { for } j=1,2, \ldots, J \text { and } c=1,2, \ldots, C,
$$

where $h_{j c}$ is the baseline hazard, which is allowed to be different across each country $\times$ targetindustry combination. $x$ is a vector of explanatory variables and $\beta$ a vector of coefficients to be estimated jointly with the baseline hazards $h_{j c}$. Equivalently, our model can be written as

$$
\ln \left[h_{j c}(t \mid x)\right]=\ln \left[h_{j c}(t)\right]+x^{\prime} \beta \quad \text { for } j=1,2, \ldots, J \text { and } c=1,2, \ldots, C .
$$

\footnotetext{
${ }^{15}$ An event indexed by $i$ is simply defined as a transaction in which firm $i$ was a target. The starting time for the risk of a subsequent transaction involving $i$ is defined as the time at which the previous transaction between $i$ and the acquiring firm is completed. Then the "failure time" $T_{i}$ measures the duration of time between two consecutive transactions involving firm $i$ as a target. $F$, the cumulative density, $S$, the survivor function, $f$, the probability density, and $h$, the hazard function are defined as

$$
\begin{aligned}
F\left(t_{i}\right) & =\operatorname{Pr}\left(T_{i} \leq t_{i}\right) \\
S\left(t_{i}\right) & =1-F\left(t_{i}\right)=\operatorname{Pr}\left(T_{i}>t_{i}\right) \\
f\left(t_{i}\right) & =\frac{d F\left(t_{i}\right)}{d t_{i}}=\frac{d\left(1-S\left(t_{i}\right)\right)}{d t_{i}}=-S^{\prime}\left(t_{i}\right) \\
h\left(t_{i}\right) & =\lim _{\Delta t_{i} \rightarrow 0} \operatorname{Pr}\left(t_{i}+\Delta t_{i}>T_{i}>t_{i} \mid T_{i}>t_{i}\right)=\frac{f\left(t_{i}\right)}{S\left(t_{i}\right)} .
\end{aligned}
$$

${ }^{16}$ Examples where this may not be the case are when new shares are issued and bought by the acquiring firm or when the firm's debt is transformed into equity.
} 
The sign of the estimated coefficients of the model can be interpreted as determining the direction in which the explanatory variables shift the natural logarithm of each of the baseline hazards. Letting the baseline hazards differ across country-industry combinations is analogous to having country $\times$ industry fixed effects, with the important difference that the non-parametric estimation also allows the shape of the baseline hazards to differ. Kalbfleisch and Prentice (1980) provide details of the procedure used to estimate the baseline hazards $h_{j c}(t)$.

\subsection{Are Crisis-Time Acquisitions Flipped More Frequently?}

Table 11 reports the results from estimating several Cox models of the following form, each with a different $D_{l}^{k j c t}$ as explained below:

$$
\ln \left[h_{j c}(t \mid x)\right]=\ln \left[h_{j c}(t)\right]+\beta D_{l}^{k j c t}+\beta_{f} f r a c_{k}+\beta_{m c} \text { controls } \boldsymbol{s}_{c t}+\epsilon_{k j c t} .
$$

The non-parametric baseline hazards $\ln \left[h_{j c}(t)\right]$ are stratified by country $\times$ target-industry. This allows the baseline hazard for each country $\times$ target-industry combination to differ in shape, while constraining the effect of each of the regressors on the individual baseline hazards to be the same. Each "row" of Table 11 shows the estimate of the coefficient $\beta$ on a dummy variable $D_{l}^{k j c t}$, for different $l \mathrm{~s}$. $D_{l}^{k j c t}$ indicates membership of transaction $k$ (in industry $j$, country $c$ at time $t$ ) to a particular set $l$. For example, $l$ could refer to the set of acquisitions by foreign acquiring firms or the set of acquisitions that took place during a crisis. The results in row 1 indicate whether acquisitions by foreign firms have a significantly different hazard compared to domestic acquisitions, and hence show the estimated coefficient on a dummy variable $D_{F}^{k j c t}$. It does so for four different samples, displayed in the four columns of the table. The negative sign of the four coefficients in row 1 indicates a lower hazard of a subsequent transaction for the average target that was bought by a foreign as opposed to a domestic acquirer. Given two acquiring firms, one foreign and the other domestic, both acquiring the same fraction of a target in the same country-industry at the same point in the business cycle, the foreign acquisition faces a lower risk of a subsequent transaction and hence has a lower turnover rate than a domestic transaction.

The next two rows in Table 11 report the turnover rates of acquisitions that were undertaken during banking crises and financial crises. The latter dummy variable assumes a value of one if there is a banking crisis, a currency crisis or both, according to Laeven and Valencia $(2008,2010)$. When looking at the full sample of countries, the turnover rates are not significantly different across crisis and normal times. Closer examination reveals that this finding is attributable to a significantly lower turnover rate of crisis-time acquisitions for Asia, balanced out by a higher turnover rate for the non-Asian sample. Note that the estimates for the banking crisis dummy and the financial

crisis dummy are identical for the Asian sample. These crises coincide in Asia according to the benchmark crisis dates (Laeven and Valencia, 2008, 2010).

The next three rows show several other features of merger duration in emerging markets. First, 
transactions between two firms in the same industry have a lower turnover rate compared with transactions involving firms in two different industries. This evidence suggests that the matches between firms in the same industry last longer than those in different industries. In addition, the transactions involving financial firms and foreign financial firms as acquirers have higher turnover rates than those involving non-financial firms and domestic non-financial firms, although the point estimates are not statistically significantly different from zero in the Asia subsample. These regressions provide a broad sense of how turnover rates differ across acquisitions, but the most pertinent conclusion to draw from these results is that transactions completed during the Asian crisis had lower turnover rates than those occurring during normal times. These acquisitions were actually flipped less often than the transactions undertaken in tranquil times. This finding is evidence against the fire-sale FDI hypothesis.

In Tables 12-14 we explore this point in more detail. Each of these tables shows the estimates of three coefficients $-\beta_{F}, \beta_{C}$ and $\beta_{F C}$ - on three dummy variables: a dummy for foreign acquisitions $D_{F}$, a dummy $D_{C}$ for a crisis, and the interaction between these two dummies $D_{F} \times D_{C}$. The control variables are unchanged. The estimated model is

$$
\ln \left[h_{j c}(t \mid x)\right]=\ln \left[h_{j c}(t)\right]+\beta_{F} D_{F}+\beta_{C} D_{C}+\beta_{F C} D_{F} \times D_{C}+\beta_{f} f r a c_{k}+\beta_{m c} \text { controls } s_{c t}+\epsilon_{k j c t} .
$$

Tables 12, 13 and 14 each look at different slices of the data - all acquisitions, acquisitions by financial firms and acquisitions between firms in the same industry.

Table 12 indicates that foreign acquisitions have a lower turnover rate than domestic ones in normal times. But crisis-time acquisitions by domestic firms have lower turnover rates than non-crisis acquisitions. The turnover of foreign acquisitions in and out of crises remains the same. Evidently, domestic and foreign acquisitions converge in terms of their turnover rates when conducted during crises. An exception to these patterns seems to be Latin America and South Africa, where none of these categories of acquisitions are different in terms of turnover rates.

For acquisitions by financial firms (Table 13), the picture is different. Here, foreign and domestic financial acquiring firms are indistinguishable in and out of crisis. This is because the turnover rates of both types of firms is lower for acquisitions completed during crises. For acquisitions conducted between firms in the same industry (Table 14), the story is similar to the entire sample of firms (Table 12). Foreign and domestic firms are different in normal times and converge during crisis times. ${ }^{17}$ Overall, there is little evidence that crisis-time acquisitions by foreign acquirers are flipped at faster rates than domestic ones.

We modify a number of details to check the robustness of the results. The model is estimated using acquisitions of $50 \%$ or above, as well as $100 \%$ acquisitions only. We vary the definition of

\footnotetext{
${ }^{17}$ It would be informative to conduct this type of analysis for the foreign financial acquisitions of financial targets, but this subsample contains only a small number of transactions, rendering the estimates unreliable.
} 
a financial crisis by first including only banking crises, then expanding the definition to include currency crises and using alternative crises dates from Reinhart and Rogoff (2009). ${ }^{18}$ Introducing these changes into the model leaves the main conclusions from this section unchanged, and these results are available upon request. In sum, there is little evidence that crisis-time foreign acquisitions are flipped at faster rates than crisis-time domestic acquisitions or normal-time foreign acquisitions, irrespective of the industrial sector in which the acquirer and target operate.

\subsection{Is Duration Correlated With External Finance Dependence?}

As noted above, financial crises may have different implications for acquisition patterns in industries that differ in their degree of dependence on external finance. For manufacturing firms, we did not uncover any evidence that external finance dependence predicted higher likelihood of a foreign acquisition during either a banking or a currency crisis. However, it remains possible that firms operating in industries that are more dependent on external finance are resold more quickly if purchased during a crisis. Acquisitions made during a fire sale may be driven by short-run, speculative motives rather than according to long-term investment plans (Acharya et al., 2011), and external-finance-dependent sectors may be more prone to acquisitions driven by such motives.

Since the availability of the measure of external finance dependence from Rajan and Zingales (1998) limits the sample to manufacturing firms, we examine the full sample and the Asian subsample only: the non-Asian sample contains too few observations on manufacturing firms to obtain reliable estimates of the baseline hazards. To keep the analysis as simple as possible, we test the hypothesis separately for foreign acquisitions and domestic acquisitions. ${ }^{19}$ We also limit attention to banking crises because currency crises in our sample affected only about $3 \%$ of all firms. We use a Cox model with the same set of controls as in the previous section, but the covariates of interest are the banking crisis dummy $D_{C}$, the measure of external finance dependence extfin $n_{j}$, and their interaction:

$$
\begin{array}{r}
\ln \left[h_{j c}(t \mid x)\right]=\ln \left[h_{j c}(t)\right]+\beta_{C} D_{C}+\beta_{\text {ext }} \text { extfin }_{j}+\beta_{\text {ext }, C} D_{C} \times \text { extfin } \\
j \\
\beta_{f} \text { frac }_{k}+\beta_{m c} \text { controls } \\
\text { ct }
\end{array}
$$

\footnotetext{
${ }^{18}$ In addition, we estimate different parametric duration models instead of the Cox model, which makes no parametric assumptions about the baseline hazard. We estimate five different duration models - Exponential, Weibull, Gompertz, lognormal, and loglogistic - each of which corresponds to a different specification of the baseline hazard. When the parametric form of the baseline hazard is correctly specified, these models yield more efficient estimates. We also estimate a shared frailty model, which corresponds closely to a random-effects model for panel data. The underlying assumption of our shared frailty model is that there is unobserved heterogeneity at the level of the target firm and that this heterogeneity is correlated for the same firm. The main results are not sensitive to these alternative specifications.

${ }^{19}$ Thus, we do not address the related question of whether domestic and foreign acquisitions differ in this respect. Doing so would require triple interaction terms, which would make the comparisons among the different subsamples difficult to interpret.
} 
The question is whether the turnover rates of foreign or domestic acquisitions that took place during crises increase with the external finance dependence of the industry to which the target belongs. Table 15 reports the estimated coefficients. The point estimates show that acquisitions during banking crises in more externally dependent sectors have a lower turnover rate, which is opposite in sign to what we would expect if fire sales were important. None of the point estimates are statistically significant for either the foreign or domestic acquisitions. There is no strong relationship between external financial dependence and the duration of the transaction.

As before, we run a number of robustness checks on these results. In the baseline specification we include only acquisitions of at least $50 \%$ for reasons explained at the beginning of this section. We vary this to include only $100 \%$ acquisitions. We also vary the definition of a financial crisis, using banking crises dates from Reinhart and Rogoff (2009). The results reported here are insensitive to these alternative assumptions. The regressions are available from the authors upon request.

\subsection{Summary of Results}

The main result in this section is that the degree of external finance dependence bears no significant relationship with the turnover rate of acquisitions in those sectors, either in or out of crises. This conclusion mirrors the earlier findings about the irrelevance of external finance dependence in predicting the likelihood of different categories of transactions during a crisis. This evidence casts further doubt on the fire-sale hypothesis.

\section{The Identity of Buyers in Flipped Deals}

An important normative implication of fire sales is the conjecture that such sales lead to misallocation of ownership. For example, if domestic firms are fundamentally more efficient users of domestic assets, but ownership passes from distressed domestic owners to foreigners during financial crises purely due to the short-term liquidity issues of all potential domestic acquirers, then we expect to observe crisis-time acquisitions being resold to domestic buyers rather than other foreign buyers once the crisis ends.

This observation motivates us to investigate the identity of the acquiring firm in those cases where assets are flipped. The questions of interest are whether foreign acquisitions during crises are resold more frequently to domestic acquirers than to foreign acquirers, and how this flipping compares to flips by domestic acquiring firms. To conduct this comparison, we estimate a linear probability model where the dependent variable is a dummy $D_{d o m}^{k, i}$ indicating whether, for a particular transaction $k$ involving firm $i$ as the target, the subsequent acquisition involving the same target $i$ had a domestic firm on the buyer side: 
$P\left(D_{d o m}^{k, i}=1 \mid \cdot\right)=\alpha+\beta_{F} D_{F}+\beta_{C} D_{C}+\beta_{F C} D_{F} \times D_{C}+\beta_{f} f r a c_{k}+\beta_{j c} \boldsymbol{\delta}_{j c}+\beta_{m c}$ controls $\boldsymbol{s}_{c t}+\epsilon_{k j c t}$.

There are 4,153 transactions involving targets that are acquired more than once, of which fewer than a third were initially bought by a foreign firm. Thus the proportion of foreign firms among acquirers who flip is actually slightly less than the proportion of foreign firms overall, which is roughly $36 \%$. Of these transactions, we focus on a subset of about 1,500 acquisitions (1,006 of them in Asia) in which controlling stakes of at least $50 \%$ were acquired. We have already restricted ourselves to a very thin slice of the data compared with the previous parts of this analysis, so we examine only the full sample and the Asian sample during banking crisis episodes. The estimation results are reported in Table 16. The robustness checks with logit regressions are not reported here, but they can be obtained from the authors upon request.

The sign and significance of the coefficients indicate that foreign acquirers are much less likely than their domestic counterparts to flip to a domestic firm, regardless of whether they make their acquisitions during crisis or normal times. Also, flips to domestic firms are equally common for the crisis- and normal-time acquisitions of foreign firms. The fact that foreign firms are less likely than domestic acquirers to flip their acquisition to domestic firms, and do not change their behavior during crises, runs counter to the fire-sale FDI hypothesis.

\section{Conclusion}

In this paper, we examine several observable implications related to the existence of fire-sale FDI during emerging-market crises. In the event of a fire sale, acquisitions (either FDI or a domestic acquisition) are more likely to be driven by short-run, speculative motives rather than by long-term investment plans. During crises, we expect to observe that foreign acquisitions increase in sectors that are more dependent on external finance; that firms acquire larger stakes because assets are temporarily undervalued; and that divestiture rates increase among crisis-time acquisitions when asset markets recover following crises. All three of these patterns are observable implications of the fire-sale FDI hypothesis.

We do not find systematic evidence for any of these phenomena related to fire-sale FDI. Our results suggest that the frequency of acquisitions by foreign firms increases during banking and currency crises, but that the increase is led by foreign non-financial acquirers targeting non-financial firms rather than by foreign financial firms acquiring domestic firms. There is no evidence that external finance dependence matters for the aggregate pattern of acquisitions during crises. Finally, during crises, there is no evidence that the frequency of controlling stakes acquired increases or that, conditional on a controlling stake being acquired, the size of the stake acquired increases. These conclusions are quite robust to alternative assumptions about empirical specification and the use 
of alternative crisis dates.

The main contribution of the paper is to conduct a duration analysis on the length of acquirertarget relationships initiated during crisis periods. Based on our analysis of the data, crisis-time FDI is indistinguishable from crisis-time domestic acquisitions, as well as FDI undertaken during non-crisis periods in terms of their likelihood of subsequent divestiture, or turnover rate. Overall, foreign and domestic financial acquiring firms are statistically indistinguishable in and out of crises. Furthermore, the degree of external finance dependence bears no significant relationship with the turnover rate of acquisitions in that sector, either in or out of crises. Finally, there is no evidence that foreign firms flip crisis-time acquisitions to domestic firms. All of these results are robust to alternative empirical specifications and different definitions of crises. Contrary to the conventional wisdom, fire-sale FDI and flipping of assets therefore seem to be "business as usual" rather than characteristic features of FDI undertaken during financial crises in emerging-market economies. 


\section{References}

V. Acharya, H. Shin, and T. Yorulmazer. Fire-sale FDI. Korean Economic Review, 27(2):163-202, 2011.

M. Aguiar and G. Gopinath. Fire-sale foreign direct investment and liquidity crises. Review of Economics and Statistics, 87:439-452, 2005.

D. D. Bergh. Predicting divestiture of unrelated acquisitions: An integrative model of ex ante conditions. Strategic Management Journal, 18:715-731, 1997.

M. Bertrand, E. Duflo, and S. Mullainathan. How much should we trust differences-in-differences estimates? Quarterly Journal of Economics, 119(1), 2004.

C. Brown and I. Dinc. Too many to fail? Evidence of regulatory forbearance when the banking sector is weak. Review of Financial Studies, 24(4), 2011.

A. C. Cameron and D. L. Miller. Robust inference with clustered data. Handbook of Empirical Economics and Finance, 2010.

A. C. Cameron, J. B. Gelbach, and D. L. Miller. Forthcoming. Robust inference with multi-way clustering. Journal of Business and Economic statistics.

J. Campbell, S. Giglio, and P. Pathak. Forced sales and house prices. American Economic Review, 101(5):2108-31, 2011.

A. Chari, P. P. Ouimet, and L. L. Tesar. The value of control in emerging markets. Review of Financial Studies, 23(4), 2010.

M. Cleves, W. Gould, R. Gutierrez, and Y. Marchenko. An Introduction to Survival Analysis Using Stata. Stata Press, 2008.

I. Erel, R. C. Liao, and M. S. Weisbach. Determinants of cross-border mergers and acquisitions. Journal of Finance, 67(3), 2012.

J. A. Frankel and A. K. Rose. Currency crashes in emerging markets: An empirical treatment. Journal of International Economics, 41(3-4), 1996.

P. D. Holan and O. Toulan. The antecedents and consequences of emerging market divestitures. Instituto de Empresa Business School Working Paper, (WP06-05), 2006.

W. C. Horrace and R. L. Oaxaca. Results on the bias and inconsistency of ordinary least squares for the linear probability model. Economics Letters, 90, 2006. 
J. D. Kalbfleisch and R. L. Prentice. The Statistical Analysis of Failure Time Data. Wiley, New York, 1980.

S. N. Kaplan and M. S. Weisbach. The success of acquisitions: Evidence from divestitures. Journal of Finance, 47:107-138, 1992.

P. Krugman. Fire-Sale FDI. University of Chicago Press, 2000.

L. Laeven and F. Valencia. Systemic banking crises: A new database. IMF Working Paper, 08/224, 2008.

L. Laeven and F. Valencia. Resolution of banking crises: The good, the bad, and the ugly. IMF Working Paper, 10/146, 2010.

P. Loungani and A. Razin. How beneficial is foreign direct investment for developing countries? Finance and Development, 38, 2001.

A. Mody and S. Negishi. Cross-border mergers and acquisitions in East Asia: Trends and implications. Finance and Development, 38, 2001.

L. E. Papke and J. M. Wooldridge. Econometric methods for fractional response variables with an application to 401 (k) plan participation rates. Journal of Applied Econometrics, 90, 1996.

M. A. Petersen. Estimating standard errors in finance panel data sets: Comparing approaches. Review of Financial Studies, 22(1), 2009.

T. C. Pulvino. Do asset fire sales exist? An empirical investigation of commercial aircraft transactions. Journal of Finance, 53:939-978, 1998.

R. Rajan and L. Zingales. Financial dependence and growth. American Economic Review, 1998.

D. J. Ravenscraft and F. M. Scherer. Divisional sell-off: A hazard function analysis. Managerial and Decision Economics, 12:429-438, 1991.

C. M. Reinhart and K. S. Rogoff. This Time is Different: Eight Centuries of Financial Folly. Princeton University Press, 2009.

S. Rossi and P. F. Volpin. Cross-country determinants of mergers and acquisitions. Journal of Financial Economics, 74(2), 2004.

A. Shleifer and R. W. Vishny. Liquidation values and debt capacity: A market equilibrium approach. Journal of Finance, 47:1343-1366, 1992.

A. Shleifer and R. W. Vishny. The limits of arbitrage. Journal of Finance, 52(1):35-55, 1997. 
Figure 1: Foreign Direct Investment Inflows and Value of Acquisitions by Foreign Firms and Region

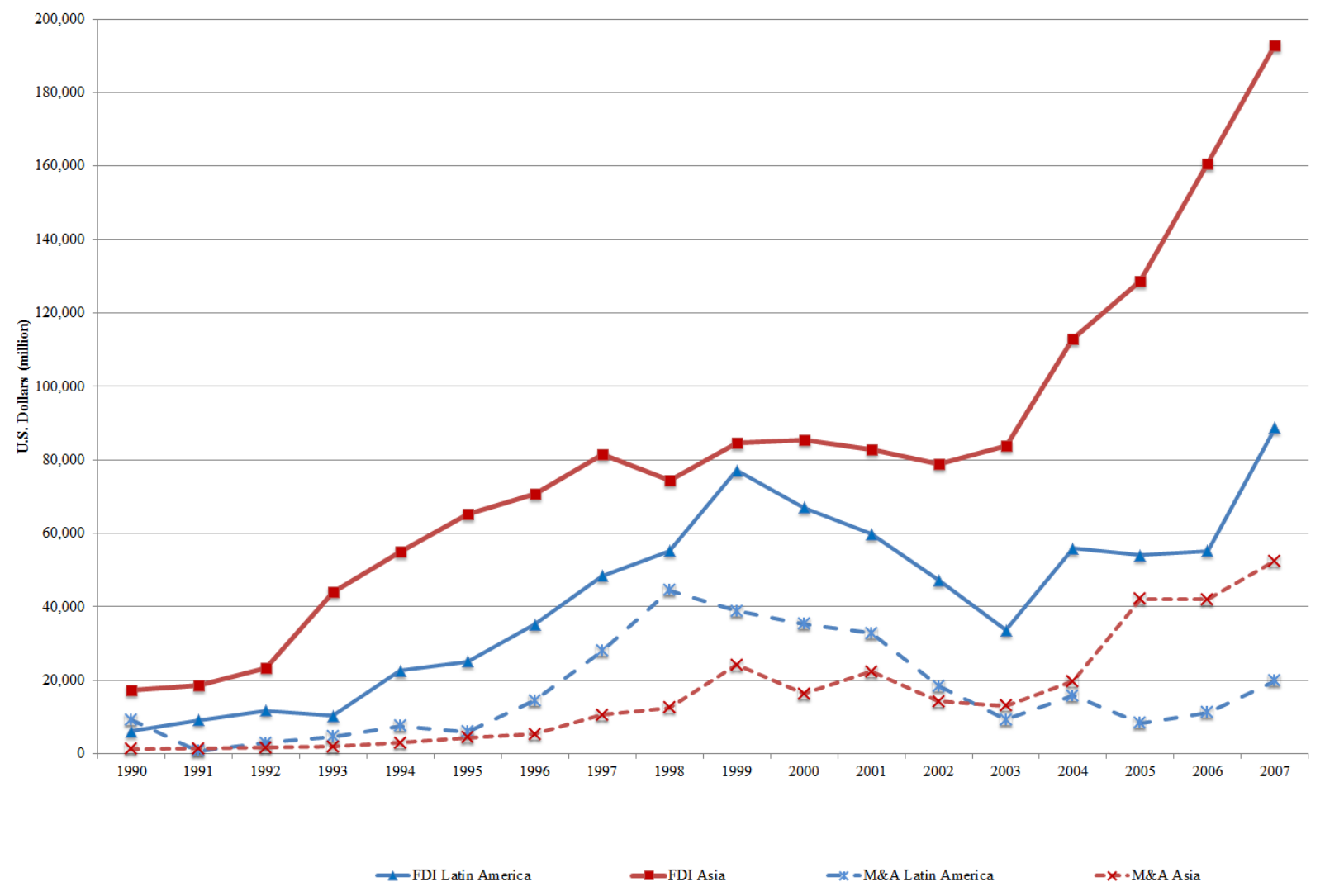

Source: UNCTAD. 
Figure 2: Acquisitions in Latin America and Asia by Foreign and Domestic Firms

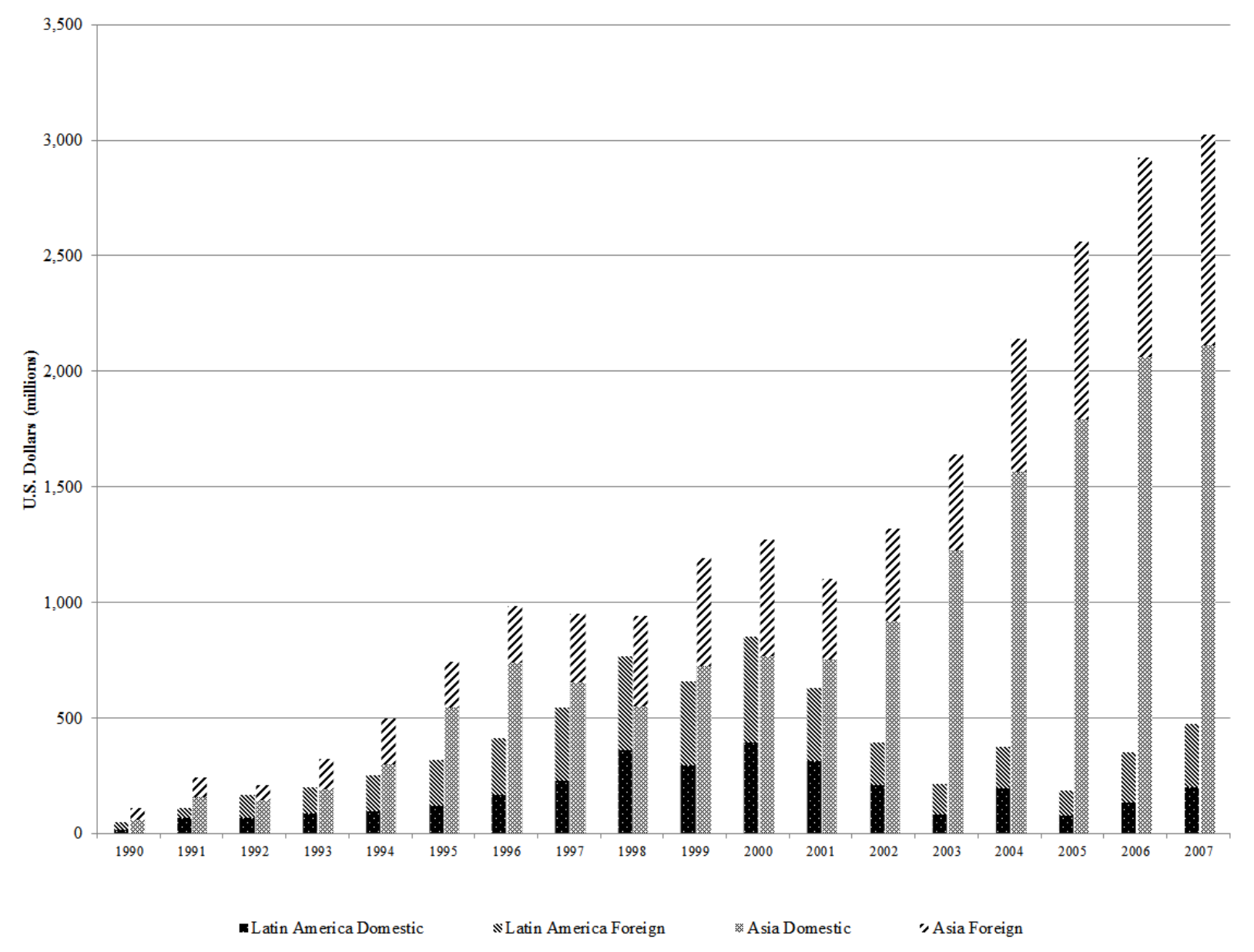

Source: UNCTAD. 


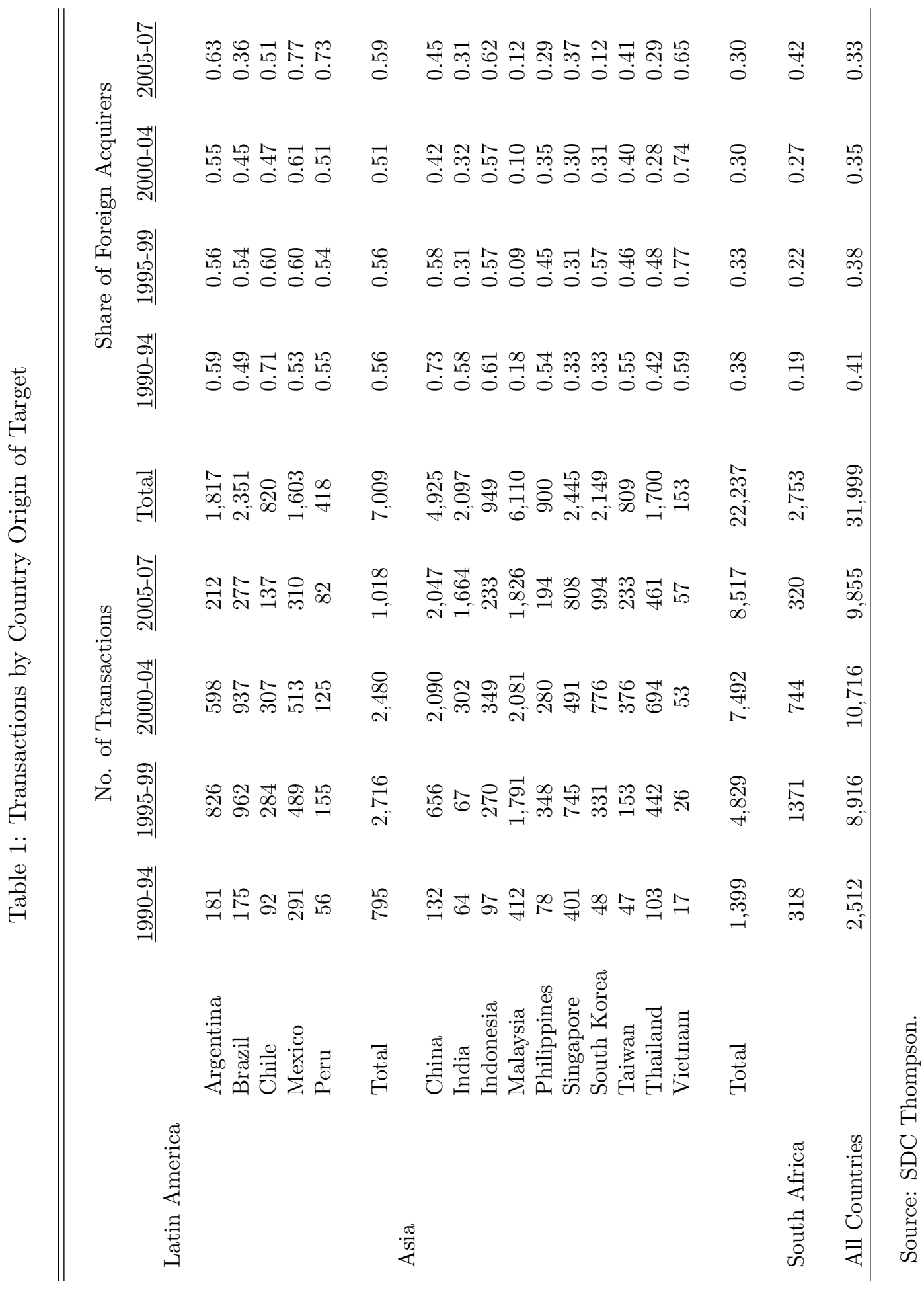




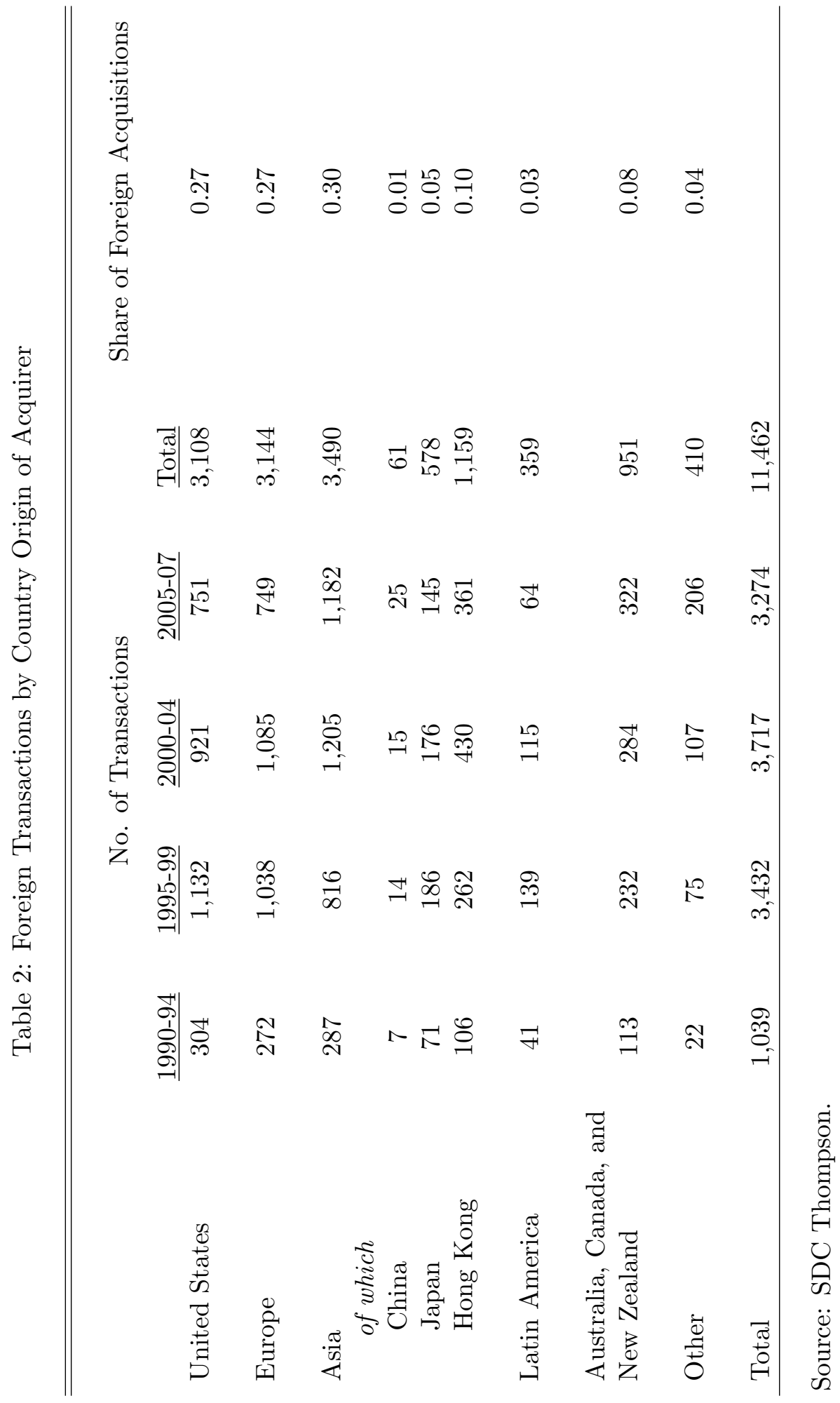


Table 3: Foreign Acquirers by Industry

\begin{tabular}{|c|c|c|c|c|c|c|}
\hline \multirow[b]{3}{*}{0} & \multirow{2}{*}{ Acquiring Firm SIC Category } & \multicolumn{2}{|c|}{ Domestic } & \multicolumn{2}{|c|}{ Foreign } & \multirow[b]{2}{*}{ Total } \\
\hline & & Freq. & Per cent & Freq. & Per cent & \\
\hline & & $\overline{299}$ & $1.5 \%$ & 85 & $0.7 \%$ & 384 \\
\hline 1 & Mining and Construction & 1,116 & $5.4 \%$ & 918 & $8.0 \%$ & 2,034 \\
\hline 2 & Manufacturing (food, textiles, petroleum) & 2,707 & $13.2 \%$ & 1,810 & $15.8 \%$ & 4,517 \\
\hline 3 & Manufacturing (rubber, electronics) & 2,933 & $14.3 \%$ & 2,190 & $19.1 \%$ & 5,123 \\
\hline 4 & Transport and Communications & 1,623 & $7.9 \%$ & 1,053 & $9.2 \%$ & 2,676 \\
\hline 5 & Wholesale and Retail & 1,121 & $5.5 \%$ & 566 & $4.9 \%$ & 1,687 \\
\hline 6 & Finance, Insurance, and Real Estate & 8,559 & $41.7 \%$ & 3,372 & $29.4 \%$ & 11,931 \\
\hline 7 & Services (hotels, amusement) & 1,459 & $7.1 \%$ & 1,087 & $9.5 \%$ & 2,546 \\
\hline 8 & Services (education, legal, other) & 680 & $3.3 \%$ & 369 & $3.2 \%$ & 1,049 \\
\hline \multirow[t]{2}{*}{9} & Public Administration & 40 & $0.2 \%$ & 12 & $0.1 \%$ & 52 \\
\hline & Total & 20,537 & $100 \%$ & 11,462 & $100 \%$ & 31,999 \\
\hline
\end{tabular}

Source: SDC Thompson. 
Table 4: Target Firms by Industry

\begin{tabular}{|c|c|c|c|c|c|c|}
\hline \multirow[b]{2}{*}{0} & \multirow{2}{*}{ Target Firm SIC Category } & \multicolumn{2}{|c|}{ Domestic } & \multicolumn{2}{|c|}{ Foreign } & \multirow[b]{2}{*}{$\frac{\text { Total }}{440}$} \\
\hline & & $\frac{\text { Freq. }}{320}$ & $\frac{\text { Per cent }}{1.6 \%}$ & $\frac{\text { Freq. }}{120}$ & $\frac{\text { Per cent }}{1.1 \%}$ & \\
\hline 1 & Mining and Construction & 1,165 & $5.7 \%$ & 1,097 & $9.6 \%$ & 2,262 \\
\hline 2 & Manufacturing (food, textiles, petroleum) & 3,199 & $15.6 \%$ & 2,054 & $17.9 \%$ & 5,253 \\
\hline 3 & Manufacturing (rubber, electronics) & 3,390 & $16.5 \%$ & 2,369 & $20.7 \%$ & 5,759 \\
\hline 4 & Transport and Communications & 2,285 & $11.1 \%$ & 1,334 & $11.6 \%$ & 3,619 \\
\hline 5 & Wholesale and Retail & 1,565 & $7.6 \%$ & 777 & $6.8 \%$ & 2,342 \\
\hline 6 & Finance, Insurance, and Real Estate & 5,383 & $26.2 \%$ & 1,904 & $16.6 \%$ & 7,287 \\
\hline 7 & Services (hotels, amusement) & 2,253 & $11.0 \%$ & 1,390 & $12.3 \%$ & 3,643 \\
\hline 8 & Services (education, legal, other) & 939 & $4.6 \%$ & 394 & $3.4 \%$ & 1,333 \\
\hline 9 & Public Administration & 38 & $0.2 \%$ & 23 & $0.2 \%$ & 61 \\
\hline & Total & 20,537 & $100 \%$ & 11,462 & $100 \%$ & 31,999 \\
\hline
\end{tabular}

Source: SDC Thompson. 


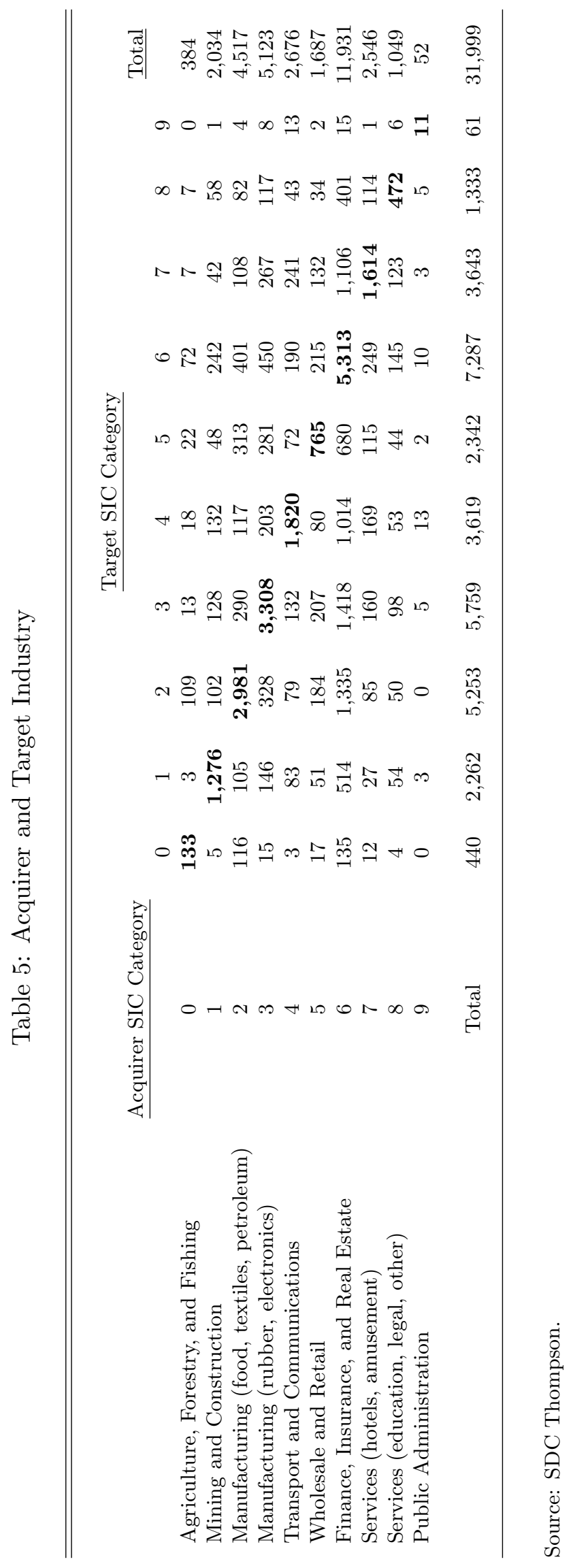


Table 6: Fraction of Target Owned by Acquirer after Transaction

\begin{tabular}{|c|c|c|c|c|c|}
\hline \multirow[t]{2}{*}{ Decile } & \multicolumn{2}{|c|}{ Domestic } & \multicolumn{2}{|c|}{ Foreign } & \multirow[b]{2}{*}{ Total } \\
\hline & Freq. & $\underline{\text { Per cent }}$ & Freq. & $\underline{\text { Per cent }}$ & \\
\hline 0-10 per cent & $\overline{1,211}$ & $5.9 \%$ & $\overline{626}$ & $5.5 \%$ & 1,837 \\
\hline $10-20$ per cent & 1,367 & $6.7 \%$ & 772 & $6.7 \%$ & 2,139 \\
\hline 20-30 per cent & 1,365 & $6.6 \%$ & 798 & $7.0 \%$ & 2,163 \\
\hline $30-40$ per cent & 933 & $4.5 \%$ & 602 & $5.3 \%$ & 1,535 \\
\hline $40-50$ per cent & 958 & $4.7 \%$ & 634 & $5.5 \%$ & 1,592 \\
\hline $50-60$ per cent & 1,712 & $8.3 \%$ & 1,122 & $9.8 \%$ & 2,834 \\
\hline $60-70$ per cent & 1,252 & $6.1 \%$ & 661 & $5.8 \%$ & 1,913 \\
\hline $70-80$ per cent & 521 & $2.5 \%$ & 297 & $2.6 \%$ & 818 \\
\hline 80-90 per cent & 758 & $3.7 \%$ & 454 & $4.0 \%$ & 1,212 \\
\hline 90-100 per cent & 589 & $2.9 \%$ & 303 & $2.6 \%$ & 892 \\
\hline 100 per cent & 9,871 & $48.1 \%$ & 5,193 & $45.3 \%$ & 15,064 \\
\hline Total & 20,537 & $100 \%$ & 11,462 & $100 \%$ & 31,999 \\
\hline Controlling Share $(\geq 50 \%)$ & 14,703 & $71.6 \%$ & 8,030 & $70.1 \%$ & 22,733 \\
\hline
\end{tabular}

Source: SDC Thompson. 
Table 7: What Type of Acquisitions Increased During Banking Crises?

\begin{tabular}{|c|c|c|c|c|c|c|}
\hline Acquirer & Target & & Full Sample & Asia & Post-1997 Asia & Non-Asia \\
\hline \multirow[t]{3}{*}{ Foreign } & \multirow[t]{3}{*}{ All } & & $\begin{array}{c}0.079^{* * *} \\
(0.02)\end{array}$ & $\begin{array}{c}0.075^{* * *} \\
(0.02)\end{array}$ & $\begin{array}{c}0.085^{* * *} \\
(0.03)\end{array}$ & $\begin{array}{c}0.060^{* *} \\
(0.02)\end{array}$ \\
\hline & & No. obs. & 31,967 & 22,217 & 19,107 & 9,750 \\
\hline & & $R^{2}$ & 0.1429 & 0.1127 & 0.1119 & 0.1087 \\
\hline \multirow[t]{4}{*}{ Foreign Fin. } & \multirow[t]{4}{*}{ All } & & $0.027^{* * *}$ & $0.019^{*}$ & $0.025^{* *}$ & $0.041^{* *}$ \\
\hline & & & $(0.01)$ & $(0.01)$ & $(0.01)$ & $(0.02)$ \\
\hline & & No. obs. & 31,967 & 22,217 & 19,107 & 9,750 \\
\hline & & $R^{2}$ & 0.0896 & 0.0731 & 0.0778 & 0.1231 \\
\hline \multirow[t]{4}{*}{ Foreign Non-Fin. } & \multirow[t]{4}{*}{ All } & & $0.051^{* * *}$ & $0.056^{* * *}$ & $0.060^{* * *}$ & 0.018 \\
\hline & & & $(0.01)$ & $(0.02)$ & $(0.02)$ & $(0.02)$ \\
\hline & & No. obs. & 31,967 & 22,217 & 19,107 & 9,750 \\
\hline & & $R^{2}$ & 0.1672 & 0.1218 & 0.1223 & 0.1475 \\
\hline \multirow[t]{4}{*}{ Foreign Non-Fin. } & \multirow[t]{4}{*}{ Non-Fin. } & & $0.052^{* * *}$ & $0.054^{* * *}$ & $0.058^{* * *}$ & 0.024 \\
\hline & & & $(0.01)$ & $(0.02)$ & $(0.02)$ & $(0.02)$ \\
\hline & & No. obs. & 31,967 & 22,217 & 19,107 & 9,750 \\
\hline & & $R^{2}$ & 0.1888 & 0.1405 & 0.1405 & 0.1733 \\
\hline \multirow[t]{4}{*}{ Foreign } & \multirow[t]{4}{*}{ Fin. } & & 0.011 & 0.014 & 0.015 & 0.007 \\
\hline & & & $(0.01)$ & $(0.01)$ & $(0.01)$ & $(0.01)$ \\
\hline & & No. obs. & 31,967 & 22,217 & 19,107 & 9,750 \\
\hline & & $R^{2}$ & 0.014 & 0.0129 & 0.0131 & 0.0179 \\
\hline \multirow[t]{4}{*}{ Foreign } & \multirow[t]{4}{*}{ Non-Fin. } & & $0.064^{* * *}$ & $0.061^{* * *}$ & $0.068^{* * *}$ & $0.043^{* *}$ \\
\hline & & & $(0.01)$ & $(0.02)$ & $(0.02)$ & $(0.02)$ \\
\hline & & No. obs. & 31,967 & 22,217 & 19,107 & 9,750 \\
\hline & & $R^{2}$ & 0.2132 & 0.1731 & 0.1707 & 0.1995 \\
\hline \multirow[t]{4}{*}{ Foreign Non-Fin. } & \multirow[t]{4}{*}{ Same Ind. } & & $0.039^{* * *}$ & $0.033^{* * *}$ & $0.035^{* * *}$ & 0.027 \\
\hline & & & $(0.01)$ & $(0.01)$ & $(0.01)$ & $(0.02)$ \\
\hline & & No. obs. & 31,967 & 22,217 & 19,107 & 9,750 \\
\hline & & $R^{2}$ & 0.1598 & 0.1082 & 0.1063 & 0.1543 \\
\hline
\end{tabular}

Notes: Point estimates of linear probability model coefficients. Coefficients marked $* * *, * *$ and $*$ are significant at $1 \%, 5 \%$ and $10 \%$, respectively. Reported coefficient is for a dummy indicating whether a transaction was completed during a domestic banking crisis, using the crisis dates from Laeven and Valencia (2010). All specifications include country $\times$ industry fixed effects, the fraction of a firm acquired and macroeconomic controls lagged 4 quarters. Standard errors, clustered twoway at the level of country $\times$ industry and month, are in parentheses. 
Table 8: Dependence on External Finance and the Probability of Acquisition

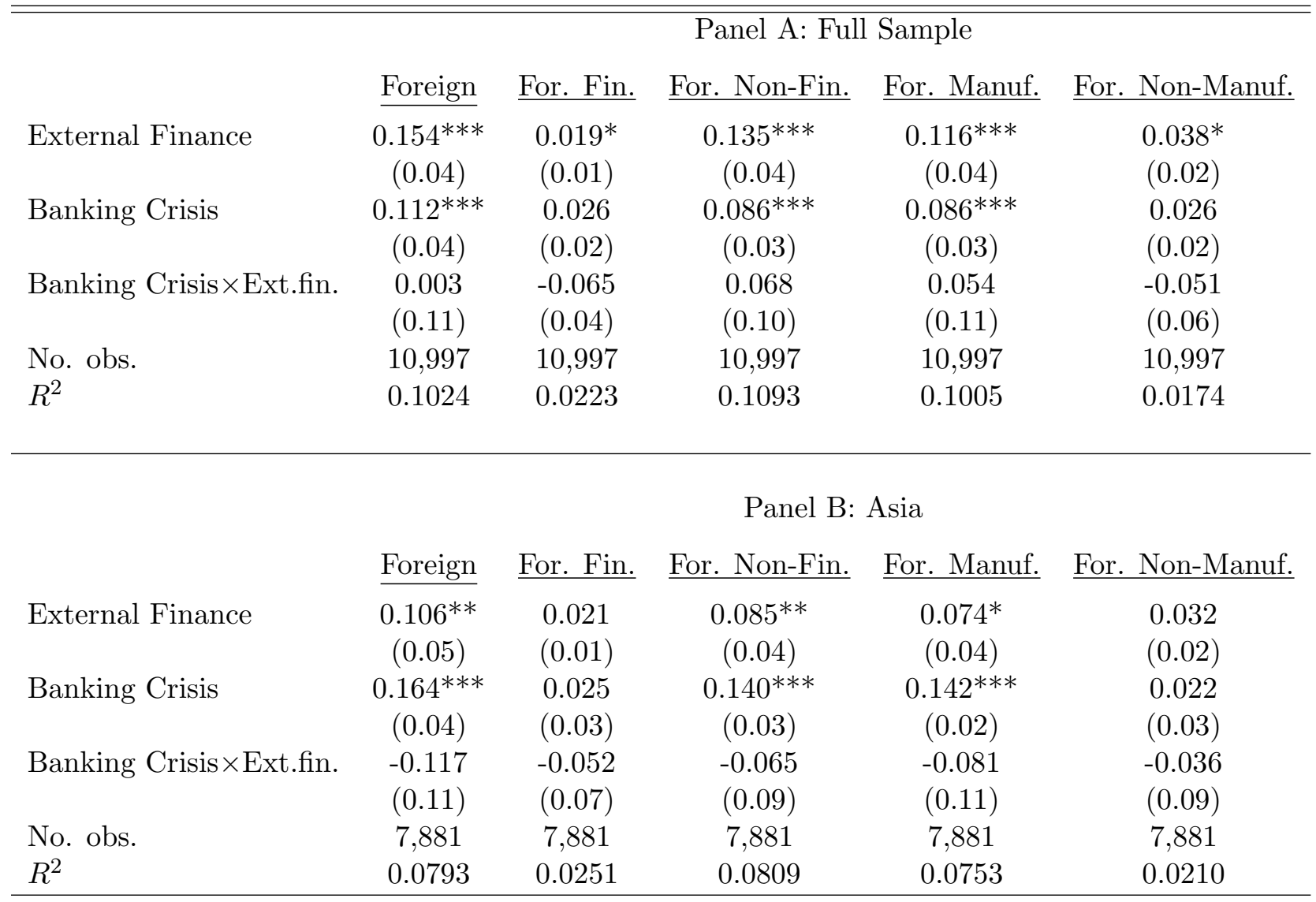

Notes: Point estimates of linear probability model regression coefficients. Coefficients marked $* * *$, $* *$ and $*$ are significant at $1 \%, 5 \%$ and $10 \%$, respectively. Banking crisis dates are from Laeven and Valencia (2010). All specifications include country fixed effects, the fraction of a firm acquired and macroeconomic controls lagged 4 quarters. Standard errors, clustered two-way at the level of country $\times$ industry and month, are in parentheses. 
Table 9: Is Control Sought More Often During Banking Crises?

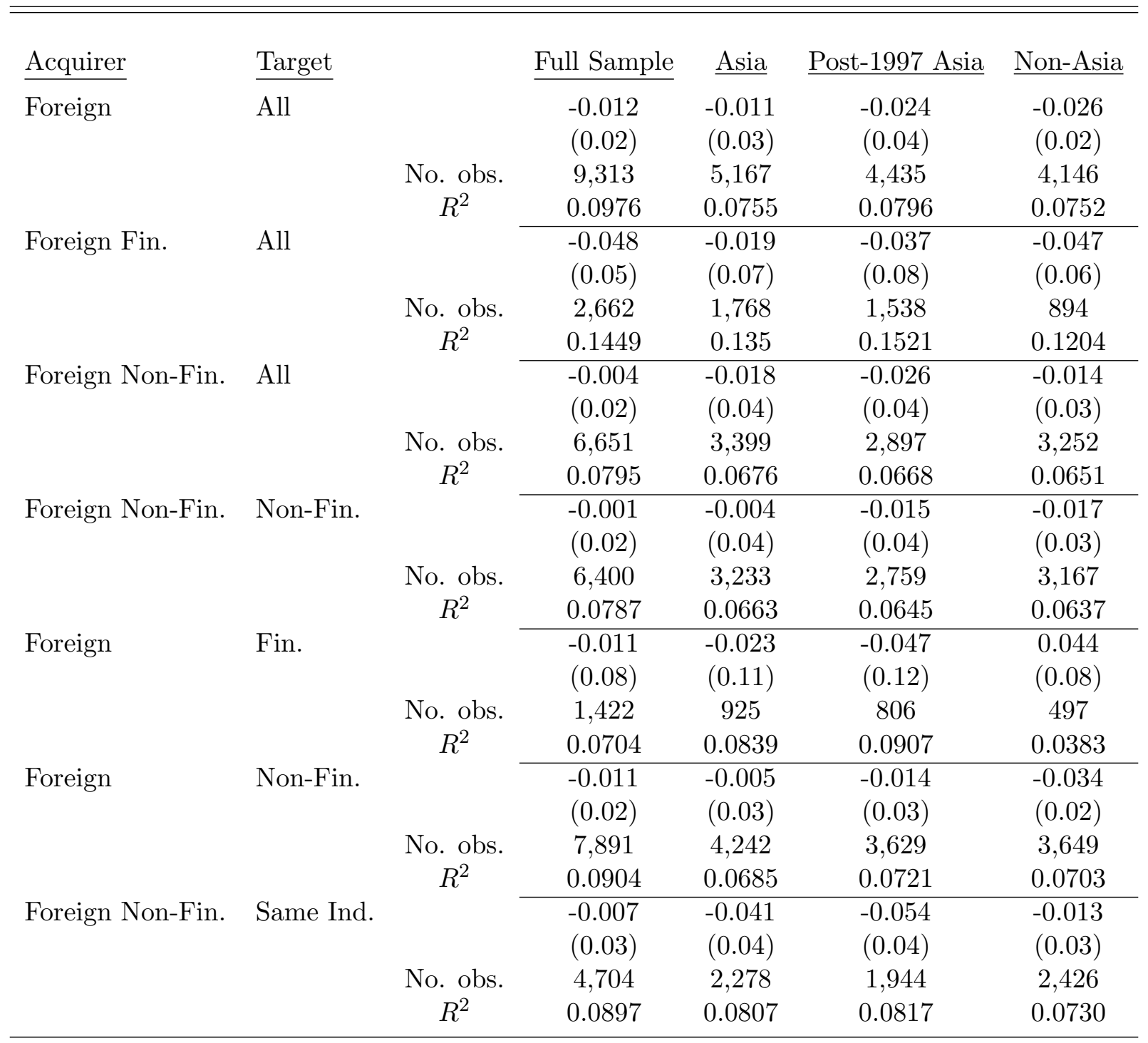

Notes: Point estimates of linear probability model coefficients. Coefficients marked $* * *, * *$ and $*$ are significant at $1 \%, 5 \%$ and $10 \%$, respectively. The dependent variable is a dummy indicating whether a controlling stake of $50 \%$ or more was acquired. Reported coefficient is for a dummy variable that shows whether the transaction was completed during a domestic banking crisis, using the crisis dates from Laeven and Valencia (2010). All specifications include country $\times$ industry fixed effects, the fraction of a firm acquired and macroeconomic controls lagged 4 quarters. Standard errors, clustered two-way at the level of country $\times$ industry and month, are in parentheses. 
Table 10: Are Larger Stakes Acquired During Banking Crises?

\begin{tabular}{|c|c|c|c|c|c|c|}
\hline Acquirer & $\underline{\text { Target }}$ & & $\underline{\text { Full Sample }}$ & $\underline{\text { Asia }}$ & $\underline{\text { Post-1997 Asia }}$ & Non-Asia \\
\hline \multirow[t]{4}{*}{ Foreign } & \multirow[t]{4}{*}{ All } & & $-0.019^{*}$ & $-0.031^{*}$ & $-0.040^{* *}$ & -0.013 \\
\hline & & & $(0.01)$ & $(0.02$ & $(0.02)$ & $(0.01)$ \\
\hline & & \multirow{4}{*}{$\begin{array}{c}\text { No. obs. } \\
R^{2}\end{array}$} & 5,710 & 2,792 & 2,438 & 2,918 \\
\hline & & & 0.0478 & 0.0456 & 0.0505 & 0.0386 \\
\hline \multirow[t]{4}{*}{ Foreign Fin. } & \multirow[t]{4}{*}{ All } & & -0.014 & -0.021 & -0.038 & 0.007 \\
\hline & & & $(0.02)$ & $(0.03)$ & $(0.04)$ & $(0.02)$ \\
\hline & & No. obs. & 1,187 & 687 & 603 & 500 \\
\hline & & $R^{2}$ & 0.1241 & 0.1064 & 0.1224 & 0.1556 \\
\hline \multirow[t]{4}{*}{ Foreign Non-Fin. } & \multirow[t]{4}{*}{ All } & & -0.02 & -0.036 & $-0.041^{*}$ & -0.015 \\
\hline & & & $(0.01)$ & $(0.02)$ & $(0.02)$ & $(0.01)$ \\
\hline & & No. obs. & 4,523 & 2,105 & 1,835 & 2,418 \\
\hline & & $R^{2}$ & 0.0506 & 0.0557 & 0.0635 & 0.0352 \\
\hline \multirow[t]{4}{*}{ Foreign Non-Fin. } & \multirow[t]{4}{*}{ Non-Fin. } & & -0.019 & -0.034 & $-0.040^{*}$ & -0.015 \\
\hline & & & $(0.01)$ & $(0.02)$ & $(0.02)$ & $(0.01)$ \\
\hline & & No. obs. & 4,371 & 2,004 & 1,752 & 2,367 \\
\hline & & $R^{2}$ & 0.0492 & 0.0523 & 0.0576 & 0.0340 \\
\hline \multirow[t]{4}{*}{ Foreign } & \multirow[t]{4}{*}{ Fin. } & & $-0.059^{* * *}$ & $-0.069^{* * *}$ & $-0.076^{* *}$ & -0.027 \\
\hline & & & $(0.02)$ & $(0.02)$ & $(0.04)$ & $(0.02)$ \\
\hline & & No. obs. & 688 & 405 & 352 & 283 \\
\hline & & $R^{2}$ & 0.0616 & 0.0743 & 0.08 & 0.0798 \\
\hline \multirow[t]{4}{*}{ Foreign } & \multirow[t]{4}{*}{ Non-Fin. } & & -0.015 & -0.024 & -0.033 & -0.013 \\
\hline & & & $(0.01)$ & $(0.02)$ & $(0.02)$ & $(0.01)$ \\
\hline & & No. obs. & 5,022 & 2,387 & 2,086 & 2,635 \\
\hline & & $R^{2}$ & 0.0465 & 0.0426 & 0.0477 & 0.0353 \\
\hline \multirow[t]{4}{*}{ Foreign Non-Fin. } & \multirow[t]{4}{*}{ Same Ind. } & & -0.018 & -0.001 & -0.006 & $-0.027^{*}$ \\
\hline & & & $(0.01)$ & $(0.02)$ & $(0.03)$ & $(0.01)$ \\
\hline & & No. obs. & 3,223 & 1,411 & 1,233 & 1,812 \\
\hline & & $R^{2}$ & 0.0597 & 0.0661 & 0.0714 & 0.0464 \\
\hline
\end{tabular}

Notes: Point estimates of OLS coefficients. Coefficients marked $* * *, * *$ and $*$ are significant at $1 \%, 5 \%$ and $10 \%$, respectively. The dependent variable is the fraction of a firm acquired, conditional on a controlling stake of $50 \%$ or more being acquired. Reported coefficient is for a dummy variable that shows whether the transaction was completed during a domestic banking crisis, using the crisis dates from Laeven and Valencia (2010). All specifications include country $\times$ industry fixed effects and macroeconomic controls lagged 4 quarters. Standard errors, clustered two-way at the level of country $\times$ industry and month, are in parentheses. 
Table 11: Merger Duration and Individual Covariates Stake Acquired $\geq 50 \%$

\begin{tabular}{lcccc}
\hline \hline & Full Sample & Asia & Post-1997 Asia & Non-Asia \\
\cline { 2 - 3 } Foreign Acq. & $-0.196^{* * *}$ & $-0.269^{* * *}$ & $-0.205^{*}$ & -0.105 \\
& $(0.07)$ & $(0.10)$ & $(0.12)$ & $(0.08)$ \\
No. obs. & 22,715 & 14,998 & 13,138 & 7,717 \\
Log $L$ & $-8,975.90$ & $-6,202.50$ & $-4,986.80$ & $-2,765.9$ \\
\hline Banking Crisis & -0.163 & $-0.358^{* * *}$ & $-0.437^{* * *}$ & 0.207 \\
& $(0.13)$ & $(0.10)$ & $(0.10)$ & $(0.17)$ \\
No. obs. & 22,715 & 14,998 & 13,138 & 7,717 \\
Log $L$ & $-8,979.50$ & $-6,202.10$ & $-4,981.50$ & $-2,765.2$ \\
\hline Financial Crisis & -0.12 & $-0.358^{* * *}$ & $-0.437^{* * *}$ & $0.314^{*}$ \\
& $(0.13)$ & $(0.10)$ & $(0.10)$ & $(0.18)$ \\
No. obs. & 22,715 & 14,998 & 13,138 & 7,717 \\
Log $L$ & $-8,980.50$ & $-6,202.10$ & $-4,981.50$ & $-2,763.5$ \\
\hline Same Industry & $-0.373^{* * *}$ & $-0.357^{* * *}$ & $-0.316^{* * *}$ & $-0.414^{* * *}$ \\
& $(0.05)$ & $(0.06)$ & $(0.06)$ & $(0.12)$ \\
No. obs. & 22,715 & 14,998 & 13,138 & 7,717 \\
Log $L$ & $-8,954.00$ & $-6,191.10$ & $-4,978.60$ & $-2,756.1$ \\
\hline Financial Acq. & $0.403^{* * *}$ & $0.320^{* * *}$ & $0.219^{* *}$ & $0.605^{* * *}$ \\
& $(0.07)$ & $(0.07)$ & $(0.09)$ & $(0.12)$ \\
No. obs. & 22,715 & 14,998 & 13,138 & 7,717 \\
Log $L$ & $-8,955.30$ & $-6,196.90$ & $-4,985.30$ & $-2,748.9$ \\
\hline For. Fin. Acq. & $0.224^{* *}$ & 0.136 & 0.127 & $0.369^{* * *}$ \\
No. obs. & $(0.10)$ & $(0.14)$ & $(0.18)$ & $(0.09)$ \\
Log $L$ & 22,715 & 14,998 & 13,138 & 7,717 \\
\hline & $-8,978.80$ & $-6,208.10$ & $-4,989.30$ & $-2,763.3$ \\
\hline
\end{tabular}

Notes: Point estimates of Cox regression coefficients. Coefficients marked $* * *, * *$ and $*$ are significant at 1\%,5\% and 10\%, respectively. Banking crisis dates are from Laeven and Valencia (2010) and Laeven and Valencia (2008). All specifications are stratified by country $\times$ industry. Also includes fraction of a firm acquired and macroeconomic controls lagged 4 quarters. Standard errors, clustered at the level of country $\times$ industry, are in parentheses. 
Table 12: The Effect of Crises on Merger Duration: All Acquirers Stake Acquired $\geq 50 \%$

\begin{tabular}{|c|c|c|c|c|}
\hline & \multicolumn{4}{|c|}{ Panel A: Banking Crisis } \\
\hline & Full Sample & $\underline{\text { Asia }}$ & $\underline{\text { Post-1997 Asia }}$ & $\underline{\text { Non-Asia }}$ \\
\hline$\beta_{F}$ & $\begin{array}{c}-0.195^{* * *} \\
(0.07)\end{array}$ & $\begin{array}{c}-0.290^{* *} \\
(0.12)\end{array}$ & $\begin{array}{r}-0.205 \\
(0.15)\end{array}$ & $\begin{array}{l}-0.019 \\
(0.08)\end{array}$ \\
\hline$\beta_{C}$ & $\begin{array}{l}-0.25 \\
(0.15)\end{array}$ & $\begin{array}{c}-0.456^{* * *} \\
(0.12)\end{array}$ & $\begin{array}{c}-0.555^{* * *} \\
(0.13)\end{array}$ & $\begin{array}{l}0.273 \\
(0.22)\end{array}$ \\
\hline$\beta_{F C}$ & $\begin{array}{c}0.064 \\
(0.17)\end{array}$ & $\begin{array}{l}0.269 \\
(0.21)\end{array}$ & $\begin{array}{l}0.175 \\
(0.23)\end{array}$ & $\begin{array}{c}-0.433 \\
(0.27)\end{array}$ \\
\hline $\begin{array}{l}\text { No. obs. } \\
\text { Log } L\end{array}$ & $\begin{array}{c}22,715 \\
-9.12460\end{array}$ & $\begin{array}{c}14,998 \\
-6.291 .00\end{array}$ & $\begin{array}{c}13,138 \\
-5.050 .10\end{array}$ & $\begin{array}{c}7,717 \\
-2,8198\end{array}$ \\
\hline \multirow[t]{3}{*}{$\begin{array}{l}H_{0}: \beta_{F}+\beta_{F C}=0 \\
H_{0}: \beta_{C}+\beta_{F C}=0\end{array}$} & $\begin{array}{l}-0.131 \\
-0.186\end{array}$ & $\begin{array}{l}-0.021 \\
-0.187\end{array}$ & $\begin{array}{c}-0.030 \\
-0.380^{*}\end{array}$ & $\begin{array}{c}-0.451^{*} \\
-0.160\end{array}$ \\
\hline & \multicolumn{4}{|c|}{ Panel B: Financial Crisis } \\
\hline & $\underline{\text { Full Sample }}$ & $\underline{\text { Asia }}$ & Post-1997 Asia & $\underline{\text { Non-Asia }}$ \\
\hline$\beta_{F}$ & $\begin{array}{c}-0.194^{* * *} \\
(0.07)\end{array}$ & $\begin{array}{c}-0.290^{* *} \\
(0.12)\end{array}$ & $\begin{array}{r}-0.205 \\
(0.15)\end{array}$ & $\begin{array}{l}0.010 \\
(0.08)\end{array}$ \\
\hline$\beta_{C}$ & $\begin{array}{c}-0.2 \\
(0.16)\end{array}$ & $\begin{array}{c}-0.456^{* * *} \\
(0.12)\end{array}$ & $\begin{array}{c}-0.555^{* * *} \\
(0.13)\end{array}$ & $\begin{array}{c}0.409^{* *} \\
(0.20)\end{array}$ \\
\hline$\beta_{F C}$ & $\begin{array}{l}0.045 \\
(0.15)\end{array}$ & $\begin{array}{c}0.269 \\
(0.21)\end{array}$ & $\begin{array}{l}0.175 \\
(0.23)\end{array}$ & $\begin{array}{c}-0.481^{* *} \\
(0.19)\end{array}$ \\
\hline No. obs. & 22,715 & 14,998 & 13,138 & 7,717 \\
\hline $\log L$ & $-9,126.20$ & $-6,291.00$ & $-5,050.10$ & $-2,818.0$ \\
\hline $\begin{array}{l}H_{0}: \beta_{F}+\beta_{F C}=0 \\
H_{0}: \beta_{C}+\beta_{F C}=0\end{array}$ & $\begin{array}{l}-0.149 \\
-0.156 \\
\end{array}$ & $\begin{array}{l}-0.021 \\
-0.187 \\
\end{array}$ & $\begin{array}{c}-0.030 \\
-0.380^{*} \\
\end{array}$ & $\begin{array}{c}-0.471^{* *} \\
-0.073 \\
\end{array}$ \\
\hline
\end{tabular}

Notes: Point estimates of Cox regression coefficients. Coefficients marked $* * *, * *$ and $*$ are significant at $1 \%, 5 \%$ and $10 \%$, respectively. Crisis dates are from Laeven and Valencia (2010). All specifications are stratified by country $\times$ industry. Also includes fraction of a firm acquired and macroeconomic controls lagged 4 quarters. Standard errors, clustered one-way at the level of country $\times$ industry, are in parentheses. 
Table 13: The Effect of Crises on Merger Duration: Financial Acquirers Stake Acquired $\geq 50 \%$

\begin{tabular}{lcccc}
\hline \hline & \multicolumn{5}{c}{ Panel A: Banking Crisis } \\
& \begin{tabular}{cccc} 
Full Sample \\
\cline { 2 - 5 }
\end{tabular} & $\underline{\text { Asia }}$ & $\underline{\text { Post-1997 Asia }}$ & Non-Asia \\
$\beta_{F}$ & 0.024 & -0.002 & 0.114 & 0.152 \\
& $(0.11)$ & $(0.18)$ & $(0.24)$ & $(0.11)$ \\
$\beta_{C}$ & -0.239 & $-0.516^{* * *}$ & $-0.699^{* * *}$ & 0.277 \\
& $(0.25)$ & $(0.19)$ & $(0.20)$ & $(0.28)$ \\
$\beta_{F C}$ & -0.11 & -0.25 & -0.421 & -0.226 \\
& $(0.30)$ & $(0.37)$ & $(0.42)$ & $(0.56)$ \\
No. obs. & 7,249 & 5,046 & 4,312 & 2,203 \\
Log $L$ & $-3,085.80$ & $-2,143.50$ & $-1,652.50$ & -931.2 \\
$H_{0}: \beta_{F}+\beta_{F C}=0$ & -0.086 & -0.253 & -0.307 & -0.074 \\
$H_{0}: \beta_{C}+\beta_{F C}=0$ & -0.349 & $-0.766^{* *}$ & $-1.120^{* * *}$ & 0.051 \\
& & & & \\
\hline
\end{tabular}

Panel B: Financial Crisis

\begin{tabular}{|c|c|c|c|c|}
\hline & Full Sample & $\underline{\text { Asia }}$ & $\underline{\text { Post-1997 Asia }}$ & Non-Asia \\
\hline \multirow[t]{2}{*}{$\beta_{F}$} & 0.002 & -0.002 & 0.114 & 0.114 \\
\hline & $(0.11)$ & $(0.18)$ & $(0.24)$ & $(0.09)$ \\
\hline \multirow[t]{2}{*}{$\beta_{C}$} & -0.185 & $-0.516^{* * *}$ & $-0.699 * * *$ & 0.472 \\
\hline & $(0.29)$ & $(0.19)$ & $(0.20)$ & $(0.40)$ \\
\hline \multirow[t]{2}{*}{$\beta_{F C}$} & 0.013 & -0.25 & -0.421 & -0.068 \\
\hline & $(0.24)$ & $(0.37)$ & $(0.42)$ & $(0.36)$ \\
\hline No. obs. & 7,249 & 5,046 & 4,312 & 2,203 \\
\hline $\log L$ & $-3,087.10$ & $-2,143.50$ & $-1,652.50$ & -929.6 \\
\hline$H_{0}: \beta_{F}+\beta_{F C}=0$ & 0.015 & -0.253 & -0.307 & 0.046 \\
\hline$H_{0}: \beta_{C}+\beta_{F C}=0$ & -0.172 & $-0.766^{* *}$ & $-1.120 * * *$ & $0.404^{*}$ \\
\hline
\end{tabular}

Notes: Point estimates of Cox regression coefficients. Coefficients marked $* * *, * *$ and $*$ are significant at $1 \%, 5 \%$ and $10 \%$, respectively. Crisis dates are from Laeven and Valencia (2010). All specifications are stratified by country $\times$ industry. Also includes fraction of a firm acquired and macroeconomic controls lagged 4 quarters. Standard errors, clustered one-way at the level of country $\times$ industry, are in parentheses. 
Table 14: The Effect of Crises on Merger Duration: Same SIC Stake Acquired $\geq 50 \%$

\begin{tabular}{lcccc}
\hline \hline \multicolumn{5}{c}{ Panel A: Banking Crisis } \\
& \multicolumn{5}{c}{ Full Sample } & $\underline{\text { Asia }}$ & $\underline{\text { Post-1997 Asia }}$ & Non-Asia \\
\cline { 2 - 5 }$\beta_{F}$ & $-0.175^{*}$ & $-0.350^{* *}$ & -0.196 & 0.040 \\
& $(0.09)$ & $(0.14)$ & $(0.16)$ & $(0.10)$ \\
$\beta_{C}$ & $-0.327^{* *}$ & $-0.497^{* *}$ & $-0.650^{* * *}$ & 0.027 \\
& $(0.16)$ & $(0.20)$ & $(0.21)$ & $(0.23)$ \\
$\beta_{F C}$ & 0.216 & 0.338 & 0.232 & -0.110 \\
No. obs. & $(0.20)$ & $(0.30)$ & $(0.33)$ & $(0.24)$ \\
Log $L$ & 13,474 & 8,385 & 7,368 & 5,089 \\
$H_{0}: \beta_{F}+\beta_{F C}=0$ & $-4,254.40$ & $-2,720.20$ & $-2,243.20$ & $-1,525.3$ \\
$H_{0}: \beta_{C}+\beta_{F C}=0$ & 0.040 & -0.012 & 0.036 & -0.070 \\
& -0.112 & -0.159 & -0.417 & -0.084 \\
\hline
\end{tabular}

Panel B: Financial Crisis

\begin{tabular}{lcccc} 
& Full Sample & $\underline{\text { Asia }}$ & Post-1997 Asia & Non-Asia \\
\cline { 2 - 3 }$\beta_{F}$ & $-0.152^{*}$ & $-0.350^{* *}$ & -0.196 & 0.117 \\
& $(0.09)$ & $(0.14)$ & $(0.16)$ & $(0.10)$ \\
$\beta_{C}$ & -0.236 & $-0.497^{* *}$ & $-0.650^{* * *}$ & 0.324 \\
& $(0.16)$ & $(0.20)$ & $(0.21)$ & $(0.20)$ \\
$\beta_{F C}$ & 0.077 & 0.338 & 0.232 & $-0.461^{* *}$ \\
& $(0.18)$ & $(0.30)$ & $(0.33)$ & $(0.19)$ \\
No. obs. & 13,474 & 8,385 & 7,368 & 5,089 \\
Log $L$ & $-4,255.80$ & $-2,720.20$ & $-2,243.20$ & $-1,523.8$ \\
$H_{0}: \beta_{F}+\beta_{F C}=0$ & -0.075 & -0.012 & 0.036 & $-0.344^{* *}$ \\
$H_{0}: \beta_{C}+\beta_{F C}=0$ & -0.158 & -0.159 & -0.417 & -0.137 \\
\hline
\end{tabular}

Notes: Point estimates of Cox regression coefficients. Coefficients marked $* * *, * *$ and $*$ are significant at $1 \%, 5 \%$ and $10 \%$, respectively. Crisis dates are from Laeven and Valencia (2010). All specifications are stratified by country $\times$ industry. Also includes fraction of a firm acquired and macroeconomic controls lagged 4 quarters. Standard errors, clustered one-way at the level of country $\times$ industry, are in parentheses. 
Table 15: Merger Duration and External Finance Dependence

\begin{tabular}{lccc}
\hline \hline & \multicolumn{3}{c}{ Panel A: Foreign Acquisitions } \\
& Full Sample & $\underline{\text { Asia }}$ & Post-1997 Asia \\
\cline { 2 - 2 } External Finance & -0.683 & -0.216 & -0.126 \\
& $(0.61)$ & $(0.69)$ & $(0.86)$ \\
Banking Crisis & 0.225 & 0.625 & 0.586 \\
& $(0.27)$ & $(0.41)$ & $(0.57)$ \\
Bank $\times$ Ext.fin. & -0.983 & -1.495 & -1.642 \\
& $(0.78)$ & $(1.03)$ & $(1.16)$ \\
No. obs. & 2,703 & 1,472 & 1,282 \\
Log $L$ & -710.9 & -363.0 & -290.8 \\
& & & \\
\hline
\end{tabular}

Panel B: Domestic Acquisitions

\begin{tabular}{|c|c|c|c|}
\hline \multirow{3}{*}{ External Finance } & Full Sample & Asia & $\underline{\text { Post-1997 Asia }}$ \\
\hline & -0.049 & 0.273 & 0.344 \\
\hline & $(0.34)$ & $(0.35)$ & $(0.35)$ \\
\hline \multirow[t]{2}{*}{ Banking Crisis } & -0.378 & -0.236 & -0.334 \\
\hline & $(0.26)$ & $(0.35)$ & $(0.39)$ \\
\hline \multirow[t]{2}{*}{ Bank $\times$ Ext.fin } & -0.326 & -1.556 & -1.732 \\
\hline & $(0.91)$ & $(1.50)$ & $(1.52)$ \\
\hline No. obs. & 4,986 & 3,605 & 3,158 \\
\hline $\log L$ & $-1,935.6$ & $-1,506.3$ & $-1,187.2$ \\
\hline
\end{tabular}

Notes: Point estimates of Cox regression coefficients. Coefficients marked $* * *, * *$ and $*$ are significant at $1 \%, 5 \%$ and $10 \%$, respectively. Crisis dates are from Laeven and Valencia (2010). All specifications are stratified by country $\times$ industry. Also includes fraction of a firm acquired and macroeconomic controls lagged 4 quarters. Standard errors, clustered at the level of country $\times$ industry, are in parentheses. 
Table 16: Identity of Buyers in Flipped Deals Stake Acquired $\geq 50 \%$

\begin{tabular}{lcc}
\hline \hline & Full Sample & Asia \\
\cline { 2 - 3 }$\beta_{F}$ & $-0.510^{* * *}$ & $-0.625^{* * *}$ \\
& $(0.04)$ & $(0.04)$ \\
$\beta_{C}$ & $-0.086^{* *}$ & -0.069 \\
& $(0.04)$ & $(0.06)$ \\
$\beta_{F C}$ & 0.131 & 0.131 \\
& $(0.08)$ & $(0.12)$ \\
No. obs. & 1,525 & 1,006 \\
$R^{2}$ & 0.3828 & 0.4363 \\
$H_{0}: \beta_{F}+\beta_{F C}=0$ & $-0.379^{* * *}$ & $-0.494^{* * *}$ \\
$H_{0}: \beta_{C}+\beta_{F C}=0$ & 0.046 & 0.062 \\
\hline
\end{tabular}

Notes: Point estimates of linear probability model coefficients. Coefficients marked $* * *, * *$ and $*$ are significant at $1 \%, 5 \%$ and $10 \%$, respectively. Dependent variable is a dummy indicating whether the acquisition was flipped to a domestic firm. Crisis dates are from Laeven and Valencia (2010). All specifications include country $\times$ industry fixed effects, the fraction of a firm acquired and macroeconomic controls lagged 4 quarters. Standard errors, clustered two-way at the level of country $\times$ industry and month, are in parentheses. 